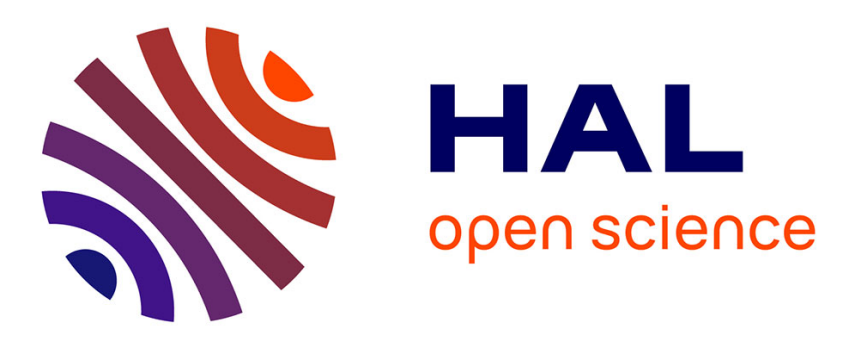

\title{
3D stratigraphic forward numerical modelling approach for prediction of organic-rich deposits and their heterogeneities
}

Benjamin Bruneau, Benoit Chauveau, François Baudin, Isabelle Moretti

\section{- To cite this version:}

Benjamin Bruneau, Benoit Chauveau, François Baudin, Isabelle Moretti. 3D stratigraphic forward numerical modelling approach for prediction of organic-rich deposits and their heterogeneities. Marine and Petroleum Geology, 2017, 82, pp.1-20. 10.1016/j.marpetgeo.2017.01.018 . hal-01446146

\section{HAL Id: hal-01446146 \\ https: / hal.sorbonne-universite.fr/hal-01446146}

Submitted on 25 Jan 2017

HAL is a multi-disciplinary open access archive for the deposit and dissemination of scientific research documents, whether they are published or not. The documents may come from teaching and research institutions in France or abroad, or from public or private research centers.
L'archive ouverte pluridisciplinaire HAL, est destinée au dépôt et à la diffusion de documents scientifiques de niveau recherche, publiés ou non, émanant des établissements d'enseignement et de recherche français ou étrangers, des laboratoires publics ou privés. 


\title{
3D stratigraphic forward numerical modelling approach for prediction
}

\section{of organic-rich deposits and their heterogeneities}

Benjamin Bruneau ${ }^{\mathrm{a}, \mathrm{b}, *}$, Benoit Chauveau ${ }^{\mathrm{c}}$, François Baudin ${ }^{\mathrm{a}}$ and Isabelle Moretti ${ }^{\mathrm{b}}$

${ }^{a}$ Sorbonne Universités, UPMC Univ Paris 06, CNRS, Institut des Sciences de la Terre de Paris (ISTeP), 4 place Jussieu 75005 Paris, France

${ }^{\mathrm{b}}$ ENGIE, Paris, France

${ }^{\mathrm{c}}$ IFP Energies Nouvelles, Rueil-Malmaison, France

* Corresponding author. UPMC Paris 06, UMR 7193, ISTeP, 75005, Paris, France. E-mail address: benjamin.bruneau@upmc.fr (B. Bruneau)

\section{Highlights:}

- First 3D process-oriented model of organic matter in Lower Jurassic European basins

- Influence of paleogeography and slope geometry on the source rock characteristics

- Organic matter distribution/heterogeneity processes are identified and quantified

\begin{abstract}
The source rock characteristics (e.g. thickness, lateral extension, richness) are known to be highly variable in both time and space. The Lower Jurassic formations of north-western Europe contain source rocks with organic-rich intervals showing different characteristics from one region to another: the Paris Basin differs from the South-East Basin of France, but organic content and hydrogen index
\end{abstract}


also vary within a single basin. During the Early Jurassic, the overall depositional environment of north-western Europe corresponded to an epicontinental domain at the western extremity of the Tethys Ocean. The early transgressive phase of the Jurassic induced flooding of this European realm. Because of the evolution of the connections and threshold of the European basins and their associated sedimentary settings, this domain occupied a key position for the deposition of organicrich layers. Using a forward modelling approach, we aim to predict the heterogeneous characteristics of such sediments. It is widely accepted that primary productivity and preservation are key factors favouring the accumulation of organic-rich layers. However, the roles of these factors remain to be assessed and the processes leading to accumulation and preservation need to be quantified.

We focus on the Lower Jurassic (Hettangian to Toarcian) in France, since this provides a vast amount of data to calibrate the 100-kyr time step model in terms of an accurate framework including paleogeography, stratigraphy, lithology, palaeontology, mineralogy and geochemistry.

Results show that favourable conditions for the deposition of organic-rich sediment can occur even with moderate primary productivity and without requiring anoxic conditions. These windows are firstly dependent on internal factors directly linked to the basin morphology, such as sedimentation rate, bathymetry and distance from the coastline. We do not need to evoke external factors such as oceanic anoxic events or enhancement of primary production to account for the deposition of organic-rich sediments. 


\section{Keywords:}

Petroleum Source Rock; Paris Basin; Liassic; Basin Modelling

\section{Introduction}

Several organic-rich layers were deposited in the north-western European basins during the Early Jurassic due to their key position in an epicontinental sea at the north-western tip of the Tethys Ocean (e.g. Fleet et al., 1988; Korte and Hesselbo, 2011; Silva et al., 2011) (Fig. 1). Since the area was rather flat, the size and geometry of the basins were strongly dependent on sea-level variations. While only a few areas remained continuously above sea level, others emerged from time to time, leading to temporary isolation of the north-western European seas from the open ocean or to the development of thresholds. The European domain was located at the western extremity of the domain affected by opening of the Tethys Ocean as well at the north-eastern margin of the future Atlantic Ocean between North America and Africa/northwestern Europe. Although this domain was only weakly affected by rifting, some small extensional faults are observed bordering the depocentres (Fig.1). The transgressive phase of the Lower Jurassic occurred during sedimentation of the organic-rich deposits. Pre-existing crustal heterogeneities (related to age of the lithosphere and faulting) induced differential responses to the sedimentary loading (Guillocheau et al., 2000). As a result, the bathymetry, connections and thresholds of the European basins evolved rapidly during the transgression, 
leading to sedimentary settings changes which have favoured the formation of organic-rich

source rocks.

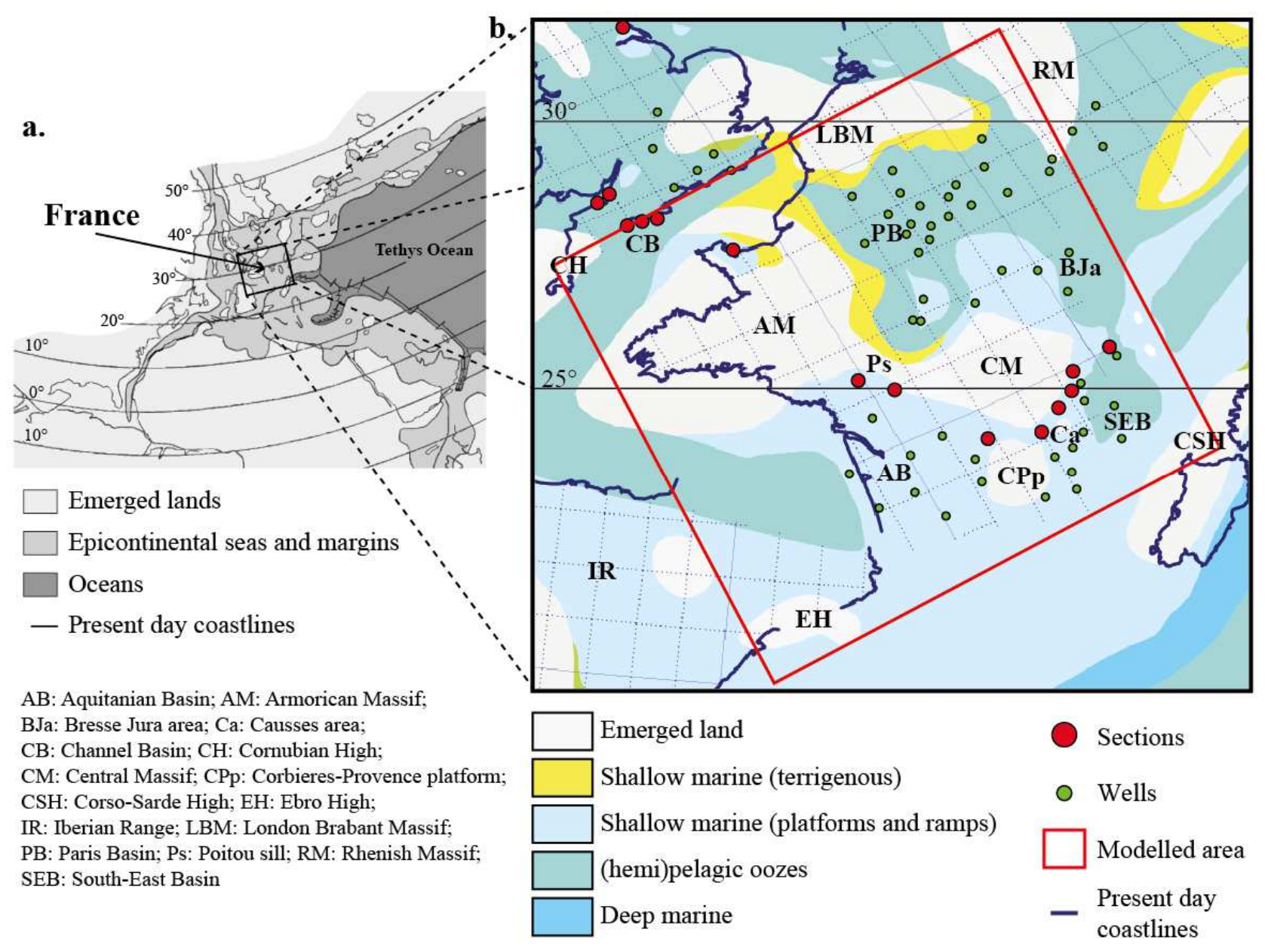

Fig. 1. a. Paleogeography of the western margin of Tethys Ocean during the Early Jurassic

(modified after Baudin et al., 1990). b. Paleogeography of the Upper Sinemurian (modified

after Thierry et al., 2010). Red and green dots indicate the studied sections and wells. 
Many studies have been carried out on Toarcian source-rocks in north-west Europe (e.g. Fleet et al., 1988; Bessereau et al., 1992), but less research has been focused on the several other organic-rich deposits of the Lower Jurassic. In the case of the Paris Basin, where the petroleum system is relatively prolific, a synthesis of the well data allows an overview of the thicknesses and richness of the three main organic-rich intervals (Bessereau et al., 1995;

Delmas et al., 2002; Fig. 2).
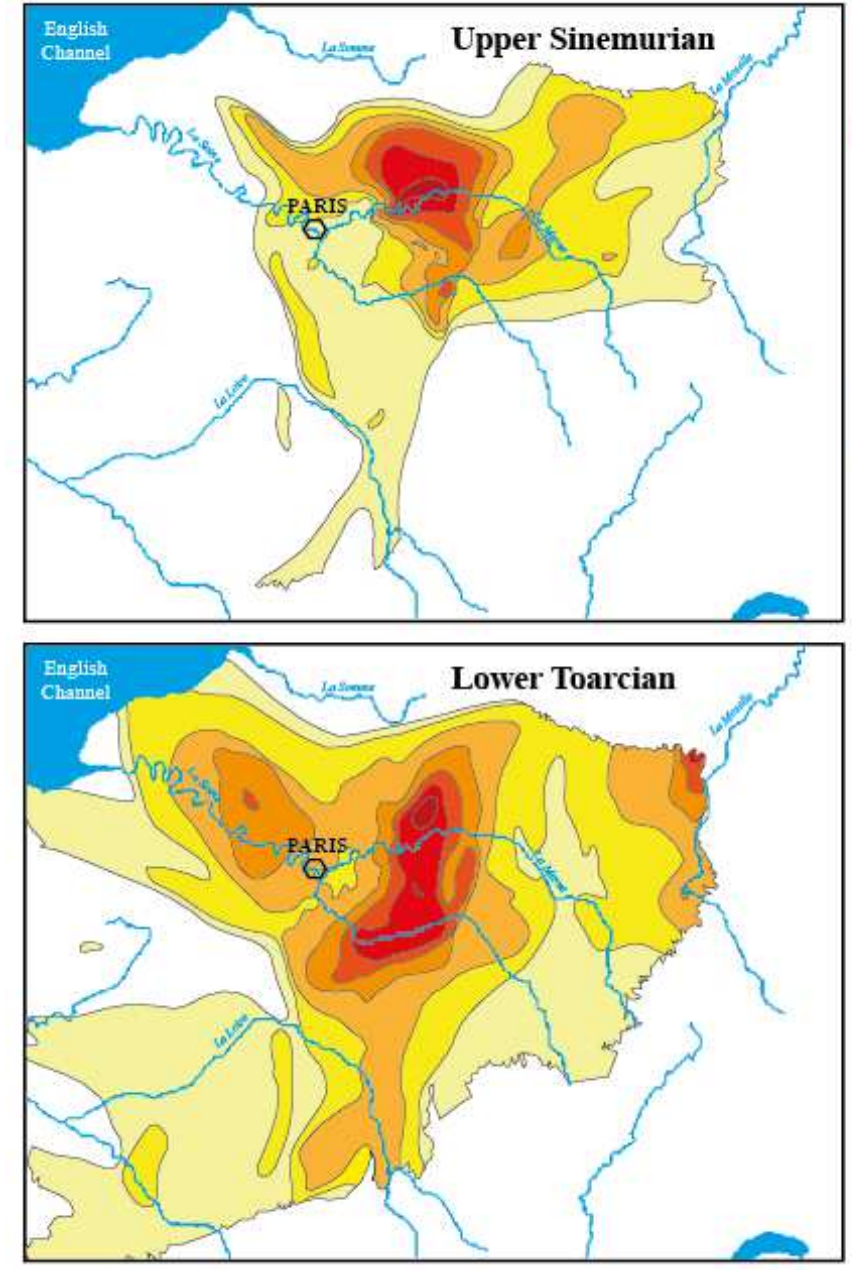

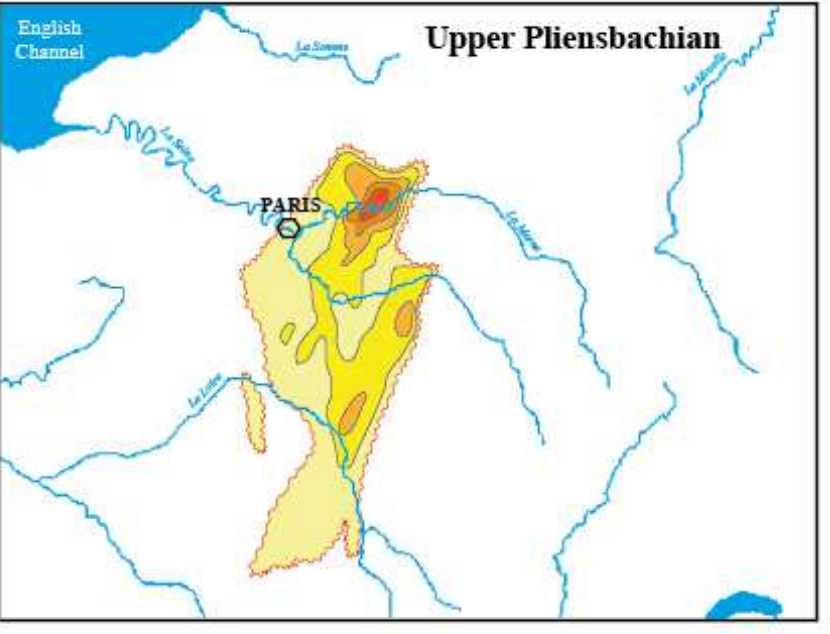

Source rock thickness

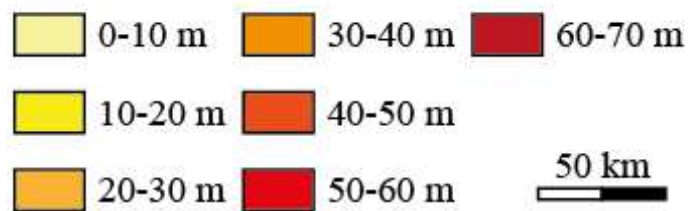

Upper Pliensbachian erosional limit

Fig. 2. Thickness variations of the three main Lower Jurassic source rocks of the Paris Basin.

The thicknesses are computed from the cumulative thicknesses of intervals with TOC > 1 wt.

\% (modified after Bessereau et al., 1992; Delmas et al., 2002). 
The spatial and temporal distributions and characteristics such as the Total Organic Content (TOC) of these organic-rich source rocks, result from a complex interaction between the processes that lead to organic matter accumulation in sediments, i.e.: primary production, transport, sedimentation, burial and degradation of organic matter. Previously, these processes were studied using specific approaches, by taking into account empirical equations or physical laws defined in the literature (e.g. Martin et al., 1987; Betts and Holland, 1991; Mann and Zweigel, 2008). Tyson (1996) proposed a theoretical model including all these processes (Fig. 3). Opposite models are those which assume that processes associated with anoxia lead to organic-rich deposits, and those where primary productivity is the main factor explaining high organic matter contents. In these conceptual models, different factors could be involved such as the presence of sills (e.g. Pompeckj, 1901; Röhl and Schmid-Röhl, 2005), basin topography (e.g. Hallam and Bradshaw, 1979; Wignall, 1991; Röhl and SchmidRöhl, 2005), variations of sea level and primary productivity (e.g. Wignall, 1991; Röhl and Schmid-Röhl, 2005) and oceanic anoxic events (e.g. Schlanger and Jenkyns, 1976). Although the conceptual model has been improved over recent decades, highlighting the relationships between the processes involved and empirical equations, there have been only few advanced numerical modelling studies (e.g. Mann and Zweigel, 2008; Bruneau et al., 2016). Thus, despite all the research carried out to date, the history of organic matter deposition processes 
need to be integrated into a 3D forward model to allow the identification and quantification of the key factors responsible for the heterogeneity of organic-rich deposits.

For this purpose, we focus on north-western Europe where four main basins developed during the Early Jurassic (Paris Basin, Aquitaine Basin and South-East Basin) separated by thresholds (e.g. Poitou sill, Bresse-Jura area) from three main emerged land masses (LondonBrabant Massif, Armorican Massif and Central Massif) (Fig. 1). This case study allows us to define various conditions for the deposition of organic-rich sediments. A 3D stratigraphic forward model of this area $(1,000 \times 1,000 \mathrm{~km})$ from the Hettangian to the Toarcian was computed with a 0.1-Myr time step. We used the DionisosFlow@ software (Granjeon, 1996, 2009; Granjeon and Joseph, 1999; Granjeon and Wolf, 2007) and its new module, which includes the simulation of organic matter contents (Granjeon and Chauveau, 2014; Bruneau et al., 2016). The validity of the model was ensured with data compiled from IFP Energies Nouvelles and ENGIE legacy databases containing field and well studies and geochemical/mineralogical analyses. 


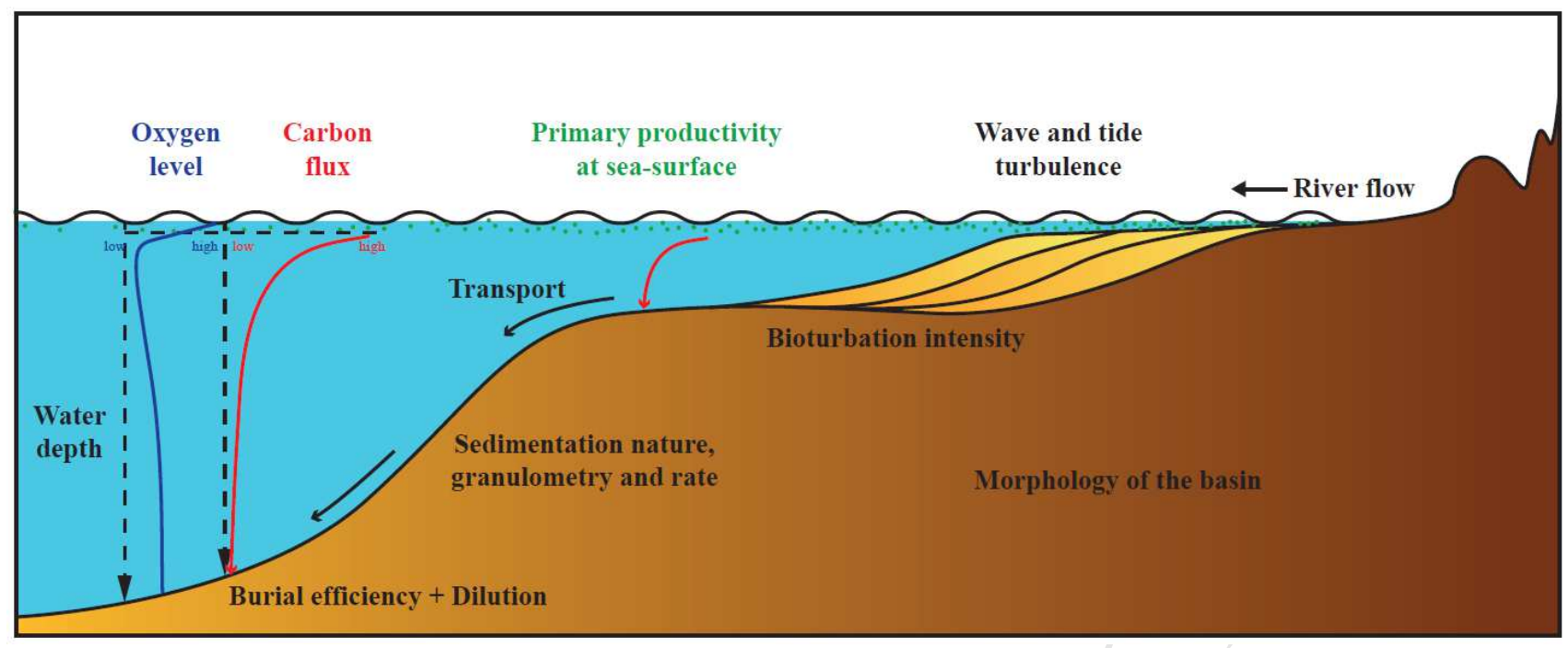

Fig. 3. Main processes affecting organic matter history, as simulated in DionisosFlow (

Organic-Rich Sediment (modified after Tyson, 1995).

The global data set shows that organic-rich deposits are not equally distributed in time. Three main periods appear to account for the deposition of about $80 \%$ of organic-rich sediments giving rise to marine source rocks (end-Devonian, Jurassic and Late Cretaceous). Global oceanic anoxic events have been proposed to explain some of these synchronous deposits (e.g. Schlanger and Jenkyns, 1976). However, as discussed by these authors (op. cit.), when using a higher resolution for the time frame, the source rocks do not appear quite so synchronous and other parameters influence the deposition and preservation of organic matter. 


\section{Geological setting}

\subsection{Structural and stratigraphic setting}

The hinged position of Europe during the opening of the Tethys and Atlantic oceans led its structural development (Fig. 1). Many horsts and grabens define areas of subsiding basins and areas of structural highs or emerged lands (Fig. 1) (e.g. Bernoulli and Jenkyns, 1974; Bassoulet and Baudin, 1994; Dromart et al., 1996). The structural setting induced differential responses to the sedimentary loading and the soft extensional tectonic context led to the reactivation of some faults which localize the subsidence (e.g. Wilson et al., 1989; Kullberg et al., 2001). Although some lower order cycles are defined (e.g. Guillocheau et al., 2000) that are often specific to each basin, two second-order cycles can be observed in most of the basins (e.g. Hardenbol et al., 1998; Guillocheau et al., 2000) (Fig. 4). The first cycle corresponds to a regressive episode at the end of the Pliensbachian, coming to an end at the Pliensbachian - Toarcian boundary. This episode is marked by a non-deposition in the proximal parts and limestone deposits in the distal parts of the basins. The transgressive second-order cycle following this regressive episode marks the maximum flooding of the Liassic transgression and is observable throughout Europe in the lower Toarcian. This surface marks the maximum flooding of European platforms and the beginning of the Toarcian anoxic episode (T-OAE) (e.g. Hesselbo et al., 2007). A further regressive phase recorded by oolitic deposits across Europe marks the end of the Early Jurassic. 


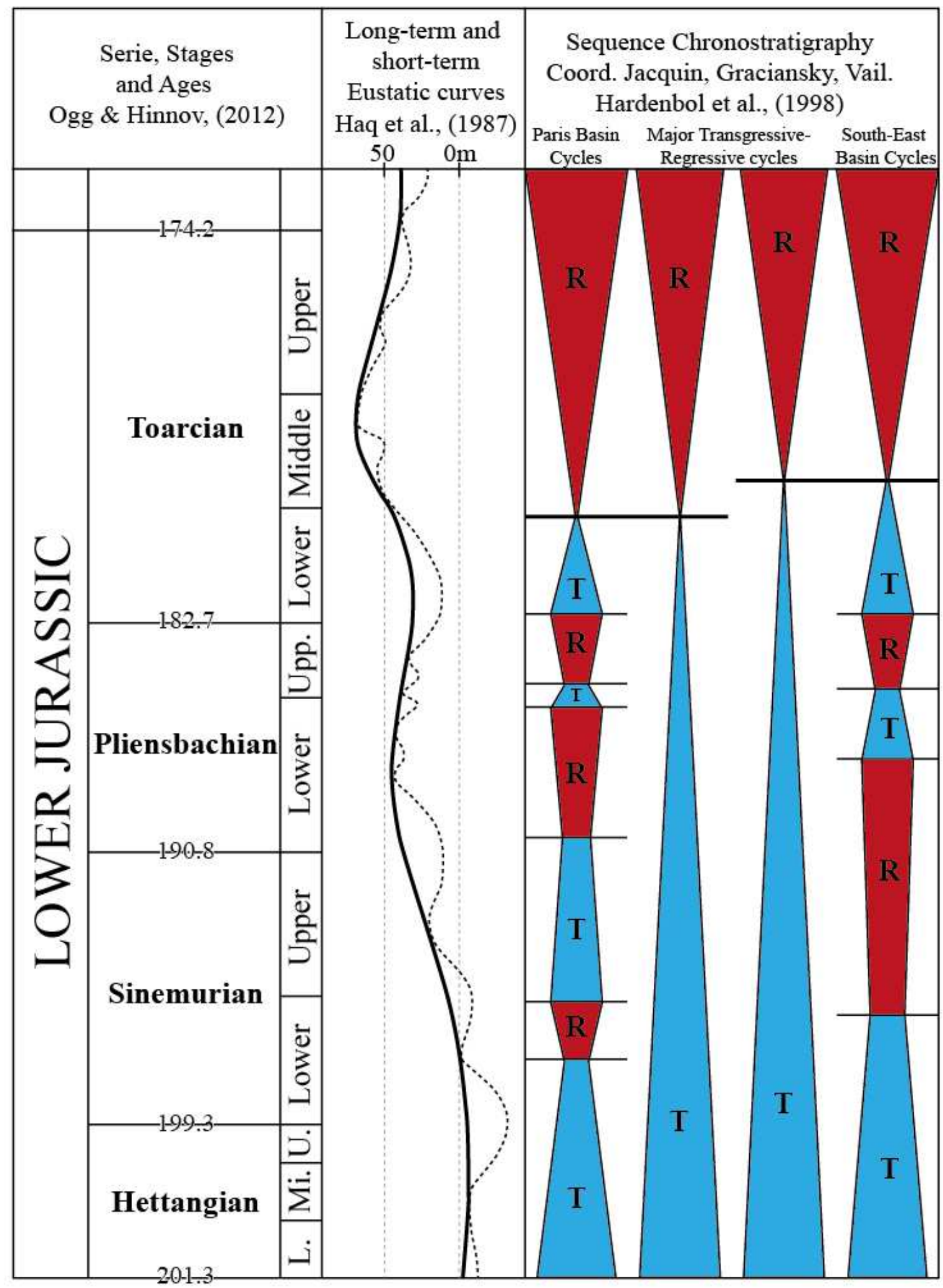

Fig. 4. Lower Jurassic sequence chronostratigraphy and eustatic variations (modified after

Hardenbol et al., 1998). 


\subsection{Toarcian oceanic anoxic event}

The Lower Toarcian sediments of north-western Europe attain high TOC values (up to 25 wt. \%), in common with other organic-rich deposits observed worldwide. Jenkyns (1988) suggested an episode of worldwide anoxic conditions named the Toarcian Anoxic Oceanic Event (T-OAE). Numerous studies have provided constraints on the timing of the T-OAE, proposing a duration of around 200 kyrs to 1 Myrs (Jenkyns, 1988; McArthur et al., 2000; Bailey et al., 2003; Mattioli et al., 2004a; Kemp et al., 2005; Boulila et al., 2014) and a synchronous development at the European scale according to the biostratigraphy (Mattioli et al., 2004a and 2004b; van Breugel et al., 2006), except for the final stages of this event (Baudin, 1989; Jenkyns et al., 2002; Mailliot, 2006; Hesselbo et al., 2007). However, the T-OAE shows a very particular context: the accumulation of organic-rich deposits occurred in epicontinental basins in Europe. Even if the T-OAE is well identified in Europe, there is a marked variability and heterogeneity of the organic matter content in sediments from one basin to another (Baudin, 1989; Baudin et al., 1990; Bassoulet and Baudin, 1994). Many models have led to hypotheses on the local and global factors explaining the T-OAE as well as other more localized anoxic events that may have occurred in Europe during the Early Jurassic (e.g. Fleet et al., 1988). 


\subsection{Biostratigraphy}

Many studies establish a detailed biostratigraphic zonation with precise resolution for this time interval (e.g. Domergues et al., 2004; Elmi, 2005; Comas-Rengifo et al., 2013; Duarte et al., 2014).

Hence in this study, chronozone intervals are determined according to the biostratigraphy of the International Commission on Stratigraphy and from recent studies or revisions of the biochronostratigraphy (see Ogg and Hinnov, 2012) (Fig.5). 


\begin{tabular}{|c|c|c|c|c|}
\hline \multicolumn{3}{|c|}{ Chronostratigraphy } & Ammonite & Top age \\
\hline \multicolumn{3}{|c|}{ AALENIAN } & & \\
\hline \multirow{22}{*}{ 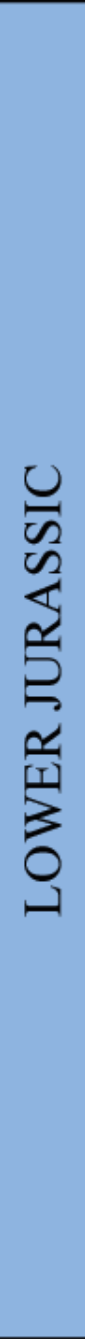 } & \multirow{8}{*}{ TOARCIAN } & \multirow{4}{*}{ UPPER } & Aalensis & 174.2 \\
\hline & & & Meneghini / Pseudoradiosa & 174.4 \\
\hline & & & Speciosum / Dispansum / Insigne & 174.7 \\
\hline & & & Bonarellii / Thouarsense & 175.0 \\
\hline & & \multirow{2}{*}{ MIDDLE } & Gradata / Variabilis & 176.2 \\
\hline & & & Bifrons & 178.2 \\
\hline & & \multirow{2}{*}{ LOWER } & Levisionis /Serpentinus /Falciferum & 180.4 \\
\hline & & & Polymorphum / Tenuicostatum & 181.7 \\
\hline & \multirow{5}{*}{ PLIENSBACHIAN } & \multirow{2}{*}{ UPPER } & Spinatum / Emaciatum & 182.7 \\
\hline & & & Margaritatus / Algovianium & 183.5 \\
\hline & & \multirow{3}{*}{ LOWER } & Davoei & 187.6 \\
\hline & & & Ibex & 188.5 \\
\hline & & & Jamesoni & 189.4 \\
\hline & \multirow{6}{*}{ SINEMURIAN } & \multirow{3}{*}{ UPPER } & Raricostatum & 190.8 \\
\hline & & & Oxynotum & 192.8 \\
\hline & & & Obtusum & 193.8 \\
\hline & & \multirow{3}{*}{ LOWER } & Turneri & 195.3 \\
\hline & & & Semicostatum & 196.3 \\
\hline & & & Bucklandi & 197.8 \\
\hline & \multirow{3}{*}{ HETTANGIAN } & UPPER & Angulata & 199.3 \\
\hline & & MIDDLE & Liasicus & 200.1 \\
\hline & & LOWER & Planorbis & 200.9 \\
\hline & \multicolumn{2}{|l|}{ RHAETIAN } & & 201.3 \\
\hline
\end{tabular}

Fig. 5. Chronostratigraphic chart for the Lower Jurassic series of the north-western European

basins. The ages given for the top of Ammonite Zones are from Ogg and Hinnov (2012). The

different names for ammonite biozones in the same time interval refer to different basins. 


\subsection{Sedimentary deposition model}

The facies distribution of the Lower Jurassic is influenced by eustatic variations and local fault activity. The shallow marine and confined depositional environments with dolomitic limestones and evaporites are replaced by carbonate ramp facies which back-step onto emerged lands. At the scale of the whole of France, the facies are mainly composed of marl-limestone alternations. In this paper, the depositional model is built from our dataset combined with field studies (Fig. 6). The subdivision of environmental settings used here is derived from Burchette and Wright (1992).

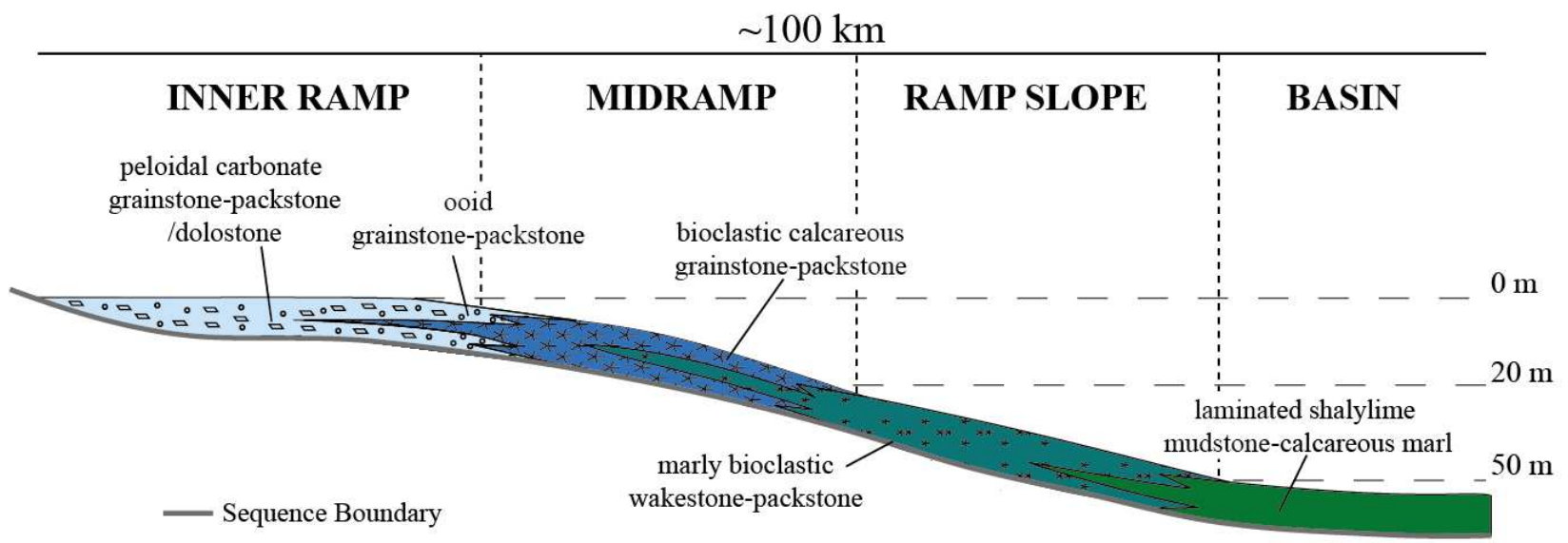

Fig. 6. Carbonate ramp settings (modified after Burchette and Wright, 1992). Inner Ramp

corresponds to a very shallow environment with potentially high-energy conditions and subaerial

emergence. The most representative facies are made up of coarse limestones and dolostones, which can be bioclastic or reworked by wave action. Midramp is a transitional shallow environment with bioclastic and bioturbated limestone facies. Ramp Slope and Basin are deeper environments below fair weather wave base. The marly component increases with water depth in these alternating marllimestone facies. 


\subsection{Characteristics of organic-rich facies}

The record of organic-rich facies is specific to each basin. The organic matter is mainly of marine type with some local influence from terrestrial inputs. In general, the organic-rich facies are attributed to episodes where marly sedimentation takes place in parallel with a substantial production of phytoplankton, in settings favourable for the development of anoxic environments. These deposits are often attributed to transgressive periods in the basins. The TOC values and mineralogical compositions within the same interval can be very variable (e.g. Espitalié et al., 1987; Hollander et al., 1991; Hanzo and Espitalié, 1993; Bessereau et al., 1995; Disnar et al., 1996). We present here a summary of our dataset (see Table 1) 


\begin{tabular}{lllll}
\hline area & & (wt. \%) & TOC (wt. \%) & (m) \\
\hline Paris & Hettangian & 2.5 & 1 to 4 & 4 to 15 \\
Paris & Upper Sinemurian & 3 & 2 to 6 & 20 to 60 \\
Paris & Lower Pliensbachian & 2 & 0.5 to 4 & 10 to 30 \\
Paris & Lower Toarcian & 5 & 3 to 7 & 20 to 70 \\
Aquitanian & Lower Toarcian & 1.2 & 0.5 to 2.8 & $?$ \\
Aquitanian & Upper Pliensbachian & 1 & 0.5 to 2 & 5 to 10 \\
South-East & Lower Toarcian & $0.2^{*}$ & 0 to $5.5^{*}$ & $*$ \\
English Channel & Hettangian/Sinemurian & 3 & 1 to 8 & 5 to 40 \\
Bresse/Jura & Lower Toarcian & 1.5 & 0.7 to 4.8 & 5 to 20 \\
Causses & Lower Toarcian & 2 & 1 to 12 & 2 to 10 \\
\hline
\end{tabular}

Table 1. Source rock characteristics of the different basins. The TOC values show strong variations from one basin to another and also over time in the same basin. The Liassic succession of the Poitou sill is nowadays eroded. * In the South-East Basin, the initial TOC values are not comparable to current TOC contents because of the strong impact of burial and maturation in this area.

In the Paris Basin, the lowermost organic-rich level (a few metres thick) in the Hettangian is located in the eastern part of the basin and is strongly influenced by terrestrial organic matter inputs with strong variations in TOC (from 0 up to 4 wt. \%). A thicker interval (up to $60 \mathrm{~m}$ ) is observed within the depocentre in the Upper Sinemurian, with an average TOC of 3 wt. \%. The base of the Pliensbachian shows a more distinct organic-rich interval attaining a thickness of $30 \mathrm{~m}$ in the southern part of the basin, with a TOC of up to $4 \mathrm{wt} . \%$. The richest interval is located at the base of the Toarcian, in the Schistes Carton Formation that can be observed throughout the basin, reaching a thickness of $70 \mathrm{~m}$ with TOC values ranging from 3 to $7 \mathrm{wt}$. \%. In the South-East Basin, thermal maturation of the Lower Jurassic deposits has led to the expulsion of most of the organic matter 
present in the source rocks, and the initial TOC is difficult to determine (e.g. Wannesson and

Bessereau, 1999). However, on the northern edge of the South-East Basin, in the Bresse/Jura area, the observations are similar to the eastern part of the Paris Basin. In the Causses area, whose connection with the South-East Basin developed during the Early Jurassic and which was less deeply buried, the TOC is very variable and, within the Toarcian, it can locally reach 12 wt. $\%$ in certain intervals several meters thick. In the English Channel Basin, the main organic-rich interval is located in the Upper Hettangian - Lower Sinemurian, and may reach a thickness of $40 \mathrm{~m}$. The TOC is very variable, with an average value of 4 wt. \% and pulses reaching 25 wt. \%. In the Aquitaine Basin, two organic-rich levels are located at the top of the Sinemurian and at the top of the Pliensbachian, showing very variable TOC (from 1 to $5 \mathrm{wt} . \%$ ) over an interval of around $10 \mathrm{~m}$. Another interval is located in the Toarcian in the centre of the basin, yielding a narrower range of TOC values (from 3 to 5 wt. \%). 


\section{Dataset and methodology}

\subsection{Dataset}

The study area covers an area of $1,000 \times 1,000 \mathrm{~km}$ extending over the whole of France (Fig. 1), and lays particular emphasis on the Lower Jurassic interval from the Lower Hettangian (201.3 Ma) to the Upper Toarcian (174.2 Ma) (Fig. 5).

The study is based on data from outcrops and boreholes in the different basins (red and green dots in Fig. 1), including structural setting, biostratigraphy, sedimentary characterization and mineralogical/geochemical analyses (29 wells including wireline logging, 12 carbologs, and more than 3000 Rock-Eval and mineralogical analyses). This dataset is built from the compilation of numerous studies cited below as well as our own field and laboratory investigations. These data are summarized in the geological setting section. They are used in the model for calibration and chronostratigraphic, lithological and geochemical control.

\subsection{Stratigraphic forward modelling}

We use the DionisosFlow@ 3D stratigraphic forward modelling software (Granjeon, 1996, 2009;

Granjeon and Joseph, 1999; Granjeon and Wolf, 2007) to reconstruct the stratigraphic and palaeo- 
geographical evolution of the studied basins during the Early Jurassic. DionisosFlow $@$ simulates the evolution of the basin geometry through time, using long-term and large-scale sediment transport equations. The results of this simulation allow us to model changes in facies distribution and sedimentation rate at the basin scale.

\subsubsection{Basin morphology construction}

Water depth varies between 0 and 250 m over the same period. The sea covers between 60 and $80 \%$ of the studied area during the Early Jurassic. The modelling starts at 200.9 Ma (Early Hettangian) and ends at 174.2 Ma (Late Toarcian), with a time step of 0.1 Ma (Fig. 5). The horizons dated at 200.9 Ma and 174.2 Ma represent the first and last time markers of the studied interval, respectively, and 7 additional horizons are used to constrain the modelling of basin evolution: 199.3 Ma (Hettangian-Sinemurian boundary), 195.3 Ma (Middle Sinemurian), 190.8 Ma (SinemurianPliensbachian boundary), 187.6 Ma (Middle Pliensbachian), 183.5 Ma (Late Pliensbachian), 182.7 Ma (Pliensbachian-Toarcian boundary), and 176.2 Ma (Middle Toarcian). Bathymetry and thickness maps of these horizons are used to compute the accommodation space, to estimate sediment production and construct the general geometry of the study area. The nine bathymetric maps (Fig. 7) are created and extrapolated from palaeo-environmental maps and the estimated water depth of each specific facies association (Thierry, 2010; Thierry and Barrier, 2010; Enay and Mangold, 1980). The nine thickness maps (Fig. 8) are created and extrapolated from subsurface data. 

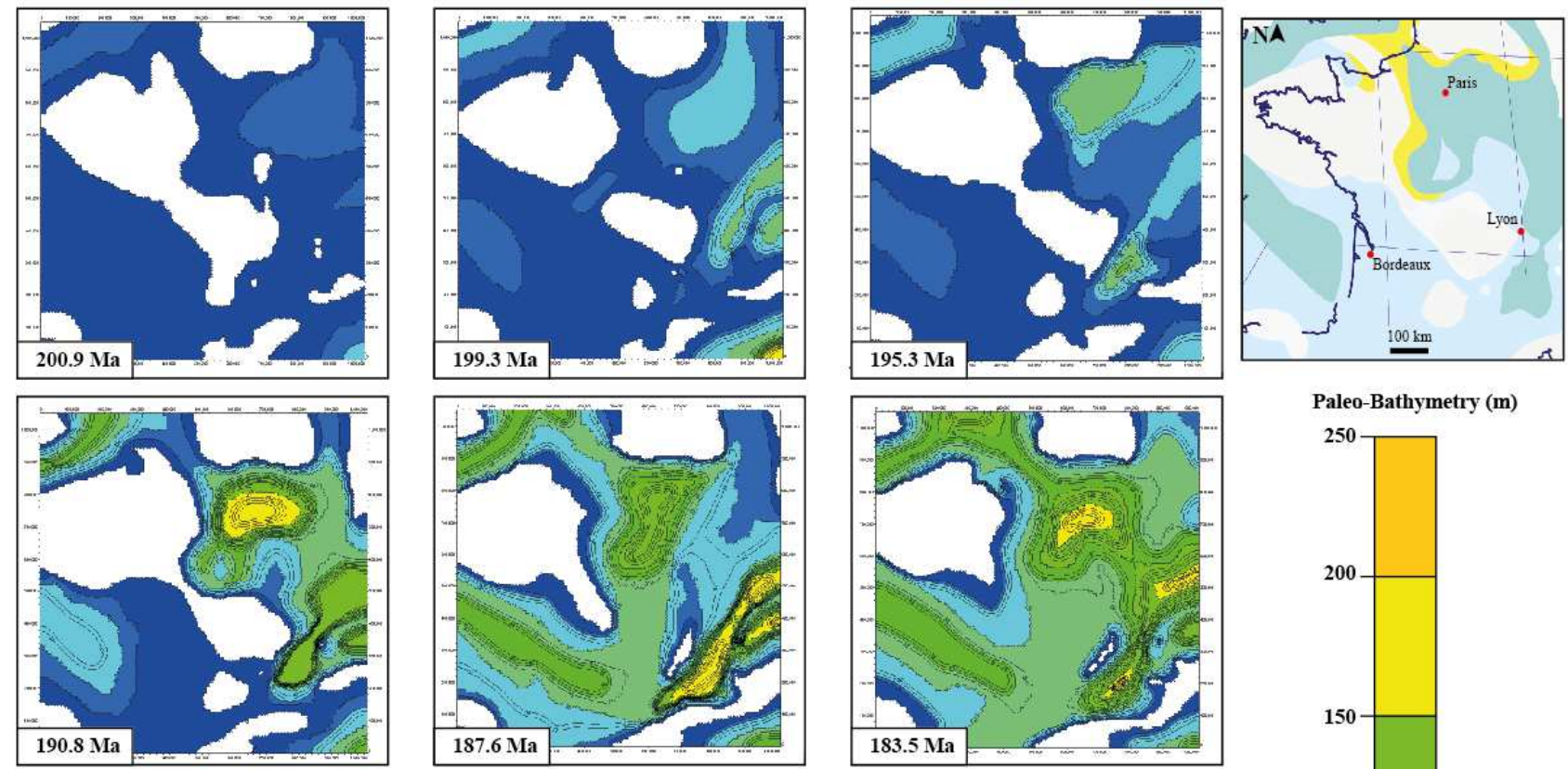

Paleo-Bathymetry (m)
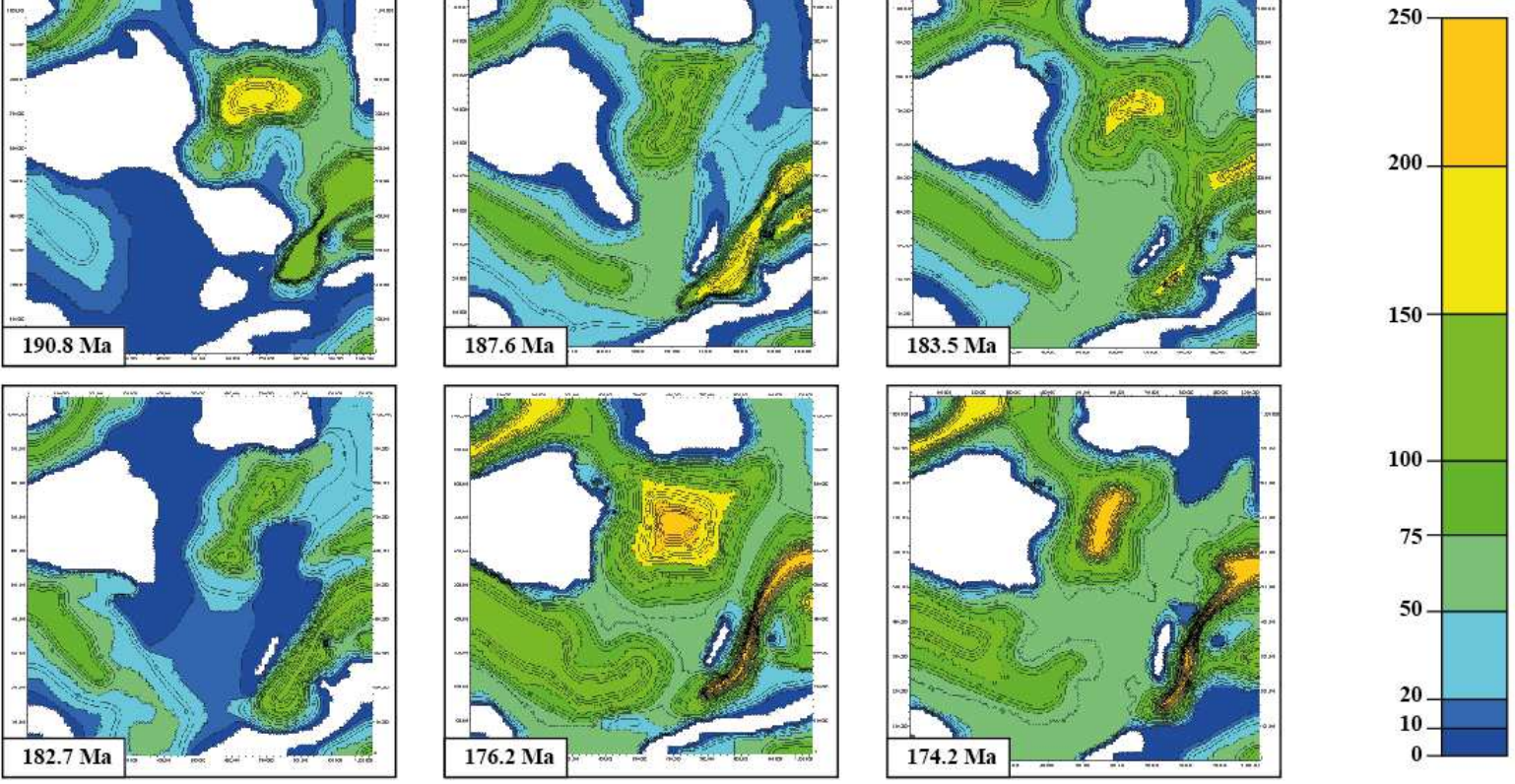

Fig. 7. Paleo-bathymetric maps of the Lower Jurassic. 

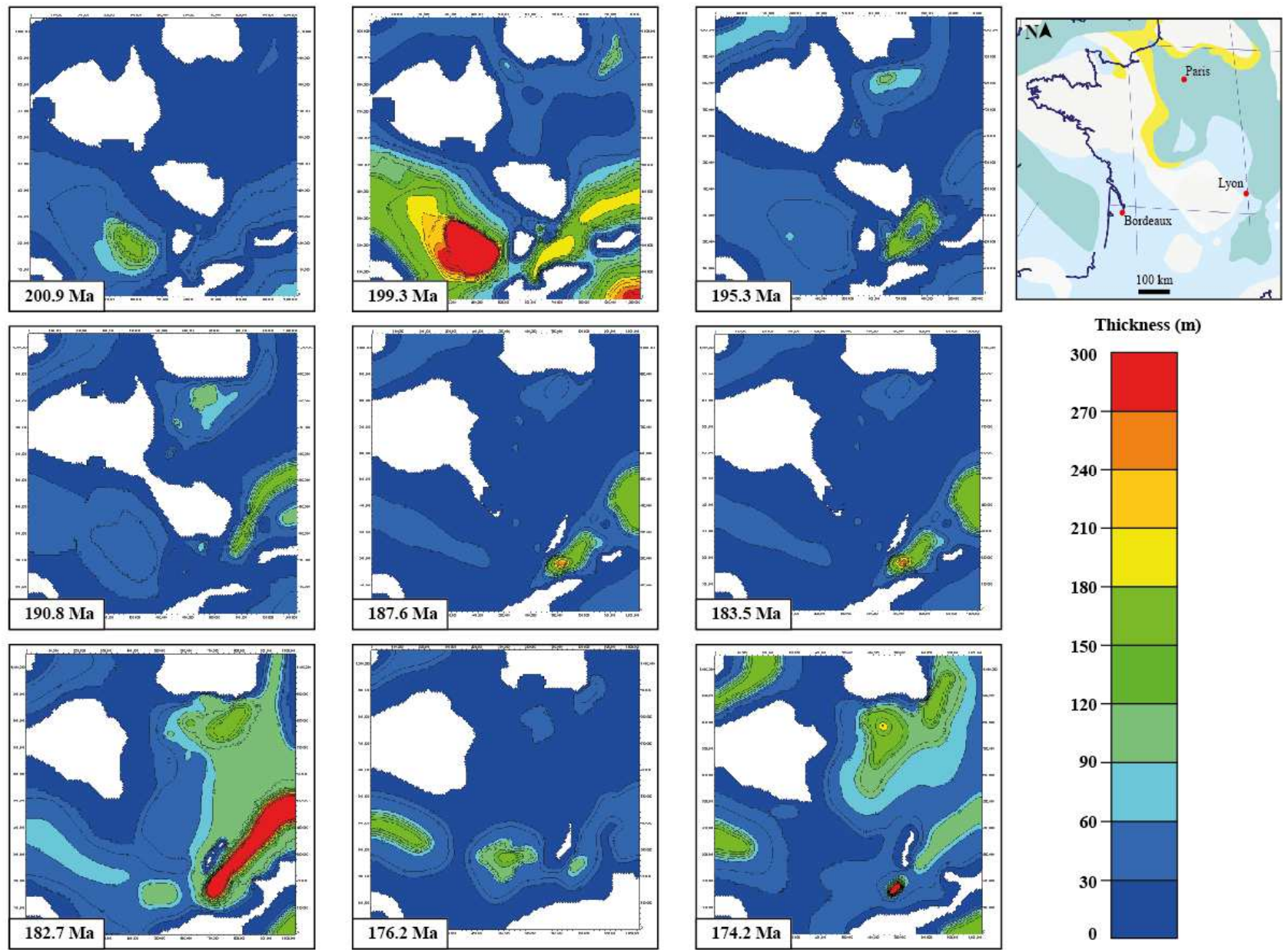

Fig. 8. Sediment thickness maps of the Lower Jurassic.

Using a backstripping methodology applied to bathymetries and thicknesses, these data allow us to

compute the available accommodation. In this way, we are able to perform simulations of sediment

production and diffusion. Backstripping is generally used to estimate tectonic subsidence by accounting for and removing the effects of other causes of subsidence, such as loading due to the sedimentary column. Here, we compute the evolution of accommodation space (Eustasy + tectonic subsidence) with the equations: 
(1) Thickness $[t]=\operatorname{Depth}[\mathrm{t}-1]-\operatorname{Depth}[\mathrm{t}]$

(2) DeltaAccommodation $[\mathrm{t}]=$ Thickness $[\mathrm{t}]+$ Bathymetry[t] - Bathymetry[t-1]

(3) Accommodation $[\mathrm{t}]=$ Accommodation $[\mathrm{t}-1]+$ DeltaAccommodation $[\mathrm{t}]$

were the thickness is corrected of the compaction effect. Sediment was assumed to be composed of three main sediment classes: sand, shale and limestone/dolostone. Compaction of each class was defined using porosity $(\Phi)$ vs. burial depth curve $(\mathrm{z})$, as described in the Figure 9 for parameters of each lithology.

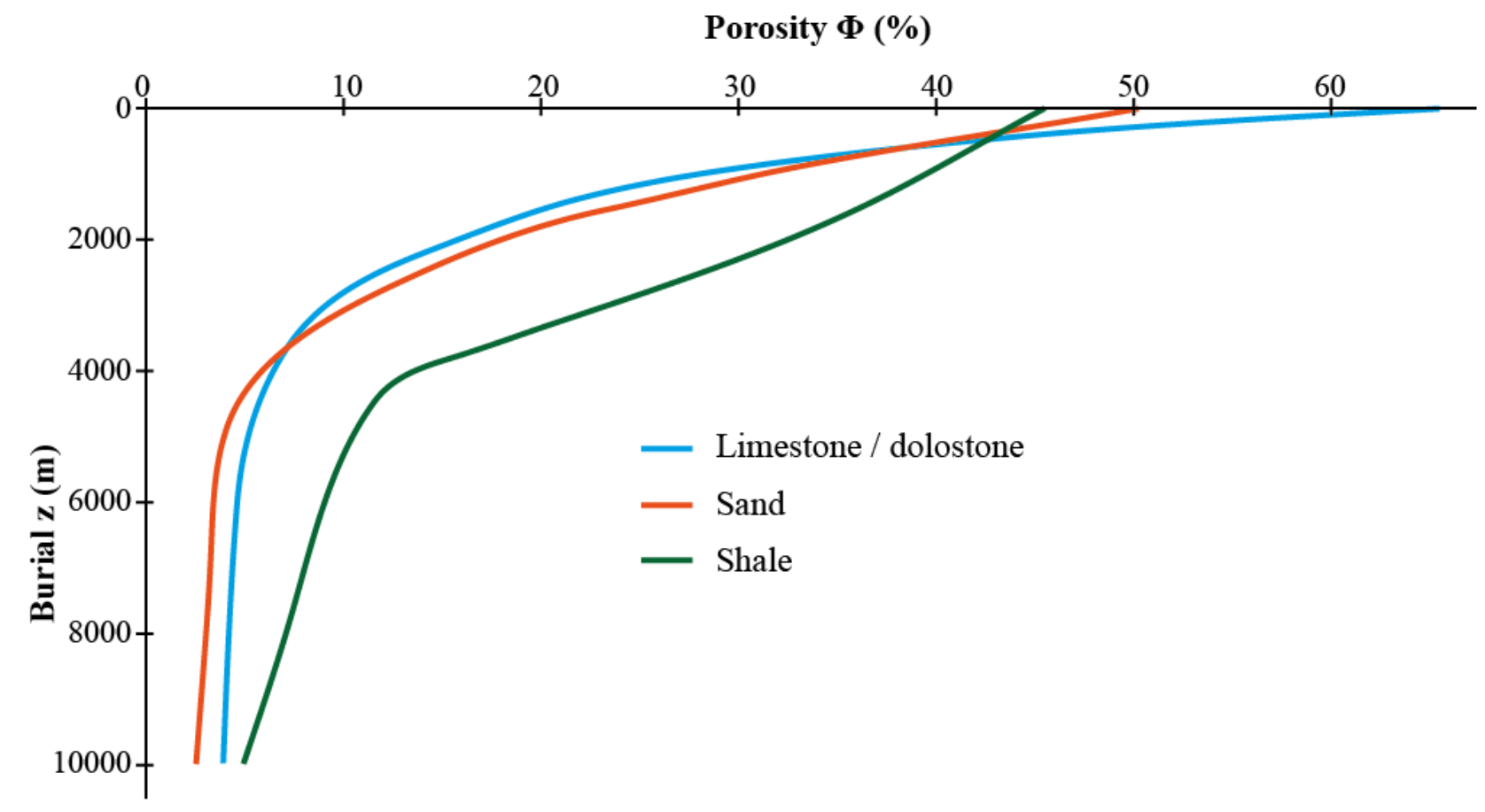

Fig. 9. Porosity function of depth for the different head member sediments of the Lower Jurassic facies. 


\subsubsection{Sediment production and diffusion}

The sediments simulated in DionisosFlow@ models are defined as a function of production and diffusion processes. Sediments are divided into in six classes for this study:

1) Fine carbonate: associated with pelagic biogenic deposits formed by primary producers in verylow-energy environments, composed of mud-supported carbonate with wackestone to mudstone textures. This sediment can be found in the low-energy basin facies; 2) Bioclastic carbonate: associated mainly with pelagic biogenic deposits but also with bioclasts, composed of mudsupported carbonates with wackestone to packstone textures. It can be found in all the facies of the ramp but mainly in the ramp-slope facies; 3) Shallow carbonate/dolostone: associated mainly with dolomite but also oolites, bioclasts, bivalves and other producer organisms in high-energy environments, composed of grain-supported carbonates with packstone to grainstone textures mainly corresponding to the inner to mid-ramp facies; 4) Shale: associated with fine clastic components of sediments associated with low-energy conditions of the basin facies; 5) Sand: associated with medium to coarse clastic component; 6) Evaporite: associated with evaporitic deposits located in confined environments.

These sediments have different transport properties based on the coupling of slow downslope linear diffusion and fast fluvial nonlinear water-driven diffusion, which allows the simulation of sediment movement at the kilometre scale and over long time spans (e.g. Rabineau et al., 2005; Alzaga-Ruiz et al., 2009). The sediments are assumed to be composed of a given number of grain-size fractions. The 
mass conservation equation is applied to each grain-size fraction. Diffusive coefficients are

discriminated according to grain size (e.g. fine-grained fractions such as shale are transported more easily because of the greater degree of sediment suspension).

The diffusion coefficients, Ks and Kw (Table 2), were defined using a simple geometrical rule assuming that sediment transport is ruled by a linear slope-driven and, for clastic inputs, a nonlinear water-driven diffusion law $(n=1.5)$ :

$Q s=S \times K s+S \times Q_{w}^{n} \times K w$

where Qs is the volume sediment flux $\left(\mathrm{km}^{2} \cdot \mathrm{kyrs}^{-1}\right), \mathrm{S}$ the slope gradient, $\mathrm{Q}_{\mathrm{w}}$ the dimensionless water flow.

\begin{tabular}{|c|c|c|c|c|c|c|}
\hline & $\begin{array}{c}\text { Fine } \\
\text { carbonate }\end{array}$ & $\begin{array}{l}\text { Bioclastic } \\
\text { carbonate }\end{array}$ & $\begin{array}{c}\text { Shallow } \\
\text { carbo/dolostone }\end{array}$ & Shale & Sand & Evaporite \\
\hline $\begin{array}{l}\text { Marine Ks } \\
\left(\mathrm{km}^{2} \cdot \mathrm{kyrs}^{-1}\right)\end{array}$ & 0.075 & 0.1 & 0.05 & 0.5 & 0.05 & 0.1 \\
\hline $\begin{array}{l}\text { Marine Kw } \\
\left(\mathrm{km}^{2} \cdot \mathrm{kyrs}^{-1}\right)\end{array}$ & & & & 1000 & 200 & \\
\hline
\end{tabular}

Table 2. Diffusion coefficients for the different sediments.

\subsubsection{Facies and thickness calibration}

Trial and error simulations are used to determine sediment production and to reproduce the thicknesses and facies observed in well and field data. Simulated Facies are defined for each cell of the model according to the bathymetry and percentage abundance of each simulated sediment type 
(Table. 3), and the simulated facies are compared against the observed facies. Figure 10 presents the

final sediment production history (function of time and bathymetry) used for the model calibration.

The best fit-model is presented in the 3D stratigraphic forward modelling section.

\begin{tabular}{lcccccc}
\hline & Shoreface & $\begin{array}{c}\text { Inner } \\
\text { Ramp }\end{array}$ & $\begin{array}{c}\text { Mid- } \\
\text { Ramp }\end{array}$ & $\begin{array}{c}\text { Ramp } \\
\text { Slope }\end{array}$ & $\begin{array}{c}\text { Basin } \\
\text { Subsiding } \\
\text { Basin }\end{array}$ \\
\hline Sand & $50-100$ & $0-50$ & $0-50$ & $0-40$ & $0-50$ & $0-30$ \\
$\begin{array}{l}\text { Shale } \\
\begin{array}{l}\text { Fine } \\
\text { carbonate }\end{array}\end{array}$ & $0-40$ & $0-40$ & $0-40$ & $0-30$ & $40-70$ & $70-100$ \\
$\begin{array}{l}\text { Shallow } \\
\text { carbo-dolo }\end{array}$ & $0-30$ & $0-30$ & $0-30$ & $0-30$ & $0-60$ & $0-30$ \\
$\begin{array}{l}\text { Bioclastic } \\
\text { carbonate }\end{array}$ & $0-50$ & $30-100$ & $0-30$ & $0-30$ & & \\
Evaporite & $0-50$ & $0-30$ & $30-100$ & $0-30$ & & \\
\hline
\end{tabular}

Table 3. Sediment composition of the simulated facies (\%). 


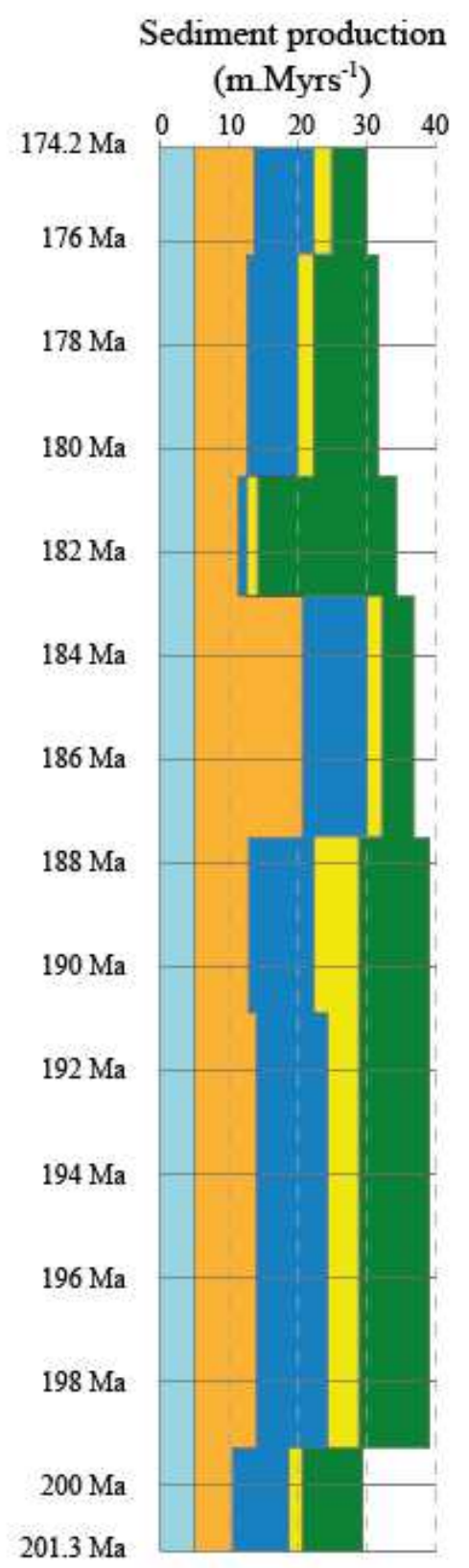

\section{a. Sedimentation production evolution through time}

Shallow carbonate/dolostone

Bioclastic carbonate

Fine carbonate

Sand*

Shale

Production

b. Prodution Ratio function of Bathymetry

Ratio

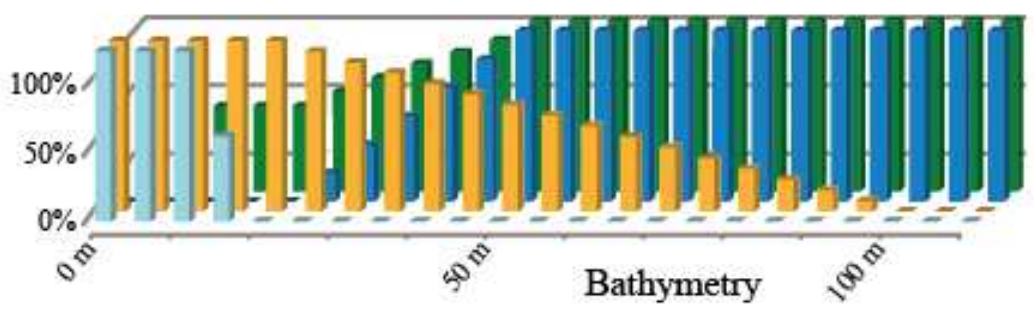

* Sand supply occur in every cells along the coast-lines (bathymetry $=0 \mathrm{~m}$ ) with a $100 \%$ ratio.

Fig. 10. Sediment production evolution function of time and bathymetry.

\subsection{Organic matter modelling}

The stratigraphic forward modelling approach provides most of the parameters required for organic matter simulation (e.g. water depth, basin morphology, sedimentation rate). New parameters are 
added into our best fit-model to simulate all the processes needed for organic matter modelling

(Granjeon and Chauveau, 2014; Bruneau et al., 2016): primary productivity, carbon flux, organic matter transport, dissolved oxygen level and burial efficiency (which corresponds to degradation within the topmost metre of burial). All these processes and their parameters are based on empirical equations or observations summarized in Granjeon and Chauveau (2014) and in Bruneau et al. (2016).

\section{Primary productivity}

We define the sea-surface primary productivity near the shore as remaining constant with time at a value of $400 \mathrm{gC} \cdot \mathrm{m}^{-2} \cdot \mathrm{yr}^{-1}$, and a seaward stepwise decrease of $100 \mathrm{gC} \cdot \mathrm{m}^{-2} \cdot \mathrm{yr}^{-1}$ is imposed every $50 \mathrm{~km}$ with a minimum value of $200 \mathrm{gC} \cdot \mathrm{m}^{-2} \cdot \mathrm{yr}^{-1}$. This seaward decrease is representative of long time scales (e.g. Berger et al., 1989; Pilson, 2012; Sathyendranath and Platt, 2013).

\section{Carbon Flux}

After primary production, the organic particles sink to the seafloor (carbon flux; e.g. Martin et al., 1987; Berger et al., 1989; Honjo et al., 2008). The exported production (CF) reaching the sea-floor interface is determined using the Martin equation (Martin et al., 1987) (i.e. an exponential decrease with water depth):

$$
C F=0.409 P P^{1.41}\left(\frac{Z}{100}\right)^{-n}
$$


where $C F$ is the exported organic flux $\left(\mathrm{gC} \cdot \mathrm{m}^{-2} \cdot \mathrm{yr}^{-1}\right), P P$ is the primary productivity $\left(\mathrm{gC} \cdot \mathrm{m}^{-2} \cdot \mathrm{yr}^{-1}\right), z$ the water depth, and $n$ is assumed to be constant and equal to 0.86 .

\section{Organic matter transport}

Once the organic remaining matter reaches the seafloor in the form of flocs, it is eventually transported. The diffusion coefficient of silt is used to mimic the transport regime of flocs at the sediment/water interface (Schieber et al., 2007). In our model, diffusion coefficients of flocs (organo-mineral aggregates) are:

Marine Ks $=0.02 \mathrm{~km}^{2} \cdot \mathrm{kyrs}^{-1}$

Marine $\mathrm{Kw}=500 \mathrm{~km}^{2} \cdot \mathrm{kyrs}^{-1}$

\section{Oxygen level}

In DionisosFlow@ Organic-Rich Sediment, a mass balance equation between oxygen renewal and oxygen consumption allows us to determine the relative oxygen depletion based on the studies of Mann and Zweigel (2008). This depletion is currently estimated without considering any water current so it is merely $1 \mathrm{D}$ (vertical):

$\frac{d O x_{z}(z)}{d t}=A_{z}(z) \times O x_{R E F}-D_{z} \times O x_{z}(z)$

where $O x_{z}$ is the oxygen level at sea-floor (expressed in nondimensional units, with values varying from 0 for fully anoxic environment to 1 for fully oxic environment), $A_{z}(z)$ is the mixing rate coefficient, $O x_{R E F}$ the reference oxygen level and $D_{z}(z)$ the oxygen consumption 
linked to organic matter degradation by organism. In our model, the mixing rate is constant in time and space and the dissolved oxygen level is therefore dependant only on bathymetry and primary productivity.

\section{Burial efficiency}

The amount of organic matter preserved after the first few metres of burial (i.e. during early diagenesis) is called burial efficiency; this parameter is mainly controlled by the sedimentation rate (Betts and Holland, 1991) and local oxygen level/redox conditions (Tyson, 1995) according to the equation:

$\frac{d \operatorname{Corg}}{d t}=-k \operatorname{Corg}^{n} \rightarrow S \frac{d \operatorname{Corg}}{d z}=-k \operatorname{Corg}^{n}$ where Corg is the quantity of available organic Carbone, $k$ the degradation coefficient (itself function of the burial depth into the sediment, $k=k_{0} e^{-z / z 0}$ ) and $S$ the sedimentation rate.

Modelling of these processes allows us to compute a theoretical initial TOC after the first few metres of burial of the marine organic matter fraction.

\section{Total organic carbon}

The Total Organic Carbon (TOC) is eventually determined with the amount of preserved organic matter diluted depending on the sedimentation rate. It corresponds to an initial TOC after the first few metres of burial of the marine organic matter fraction. Bruneau et al. (2016) provided detailed sensitivity analyses of this initial TOC distribution with several sets of parameters for the processes 
described before. In the rest of the study, "simulated TOC" refer to TOC obtained by modelling. This

TOC is calculated as an average value by cell $(10 \times 10 \mathrm{~km})$ and by time step (100 kyrs). This

resolution imply some caveats when comparing simulated TOC with TOC from well and field data.

However, the equations described in this section, are proper to large time and space scales, and the simulation of the processes governing organic matter distribution is relevant.

\section{Results}

\subsection{Best fit-model}

Following the above detailed methodology, the 3D model is computed for the basins studied here based on subsurface data, field observations and measurements (Fig. 11). The volume and the distribution of sediments in the basin are defined using trial and error simulations to reproduce observed thicknesses and facies. The simulated facies, which are used to compare observed facies, are defined for each cell of the model according to the percentage of each simulated sediment. The average sediment thickness error between simulation and real thickness is usually less than $10 \%$ (around $50 \mathrm{~m}$ on the total sediment column simulated in the Paris Basin). Both vertical and lateral simulated facies variations match with interpreted data from field studies and the literature. Only few cells show discrepancies linked to the difficulty in precisely reproducing the lateral facies changes. 
In such cases, cells with appropriate facies can be found within a maximum radius of 2 cells $(10 \mathrm{~km})$ from the calibration point.

In detail, some local discrepancies remain concerning the modelled thickness and facies compared with the present-day situation, since changes of thickness due to post-depositional deformation are not taken into account (except for effects due to compaction). In the eastern part of the South-East Basin, the discrepancy reaches $10 \%$ due to deformation of the Cretaceous-Cenozoic Alpine orogenic phase. Other minor differences in thickness may be due to the difficulty of assigning production values for each sedimentary facies in all the basins. In spite of this complexity, the facies and thicknesses computed from the 3D model are in agreement with all the major geological features observed in the basins. 


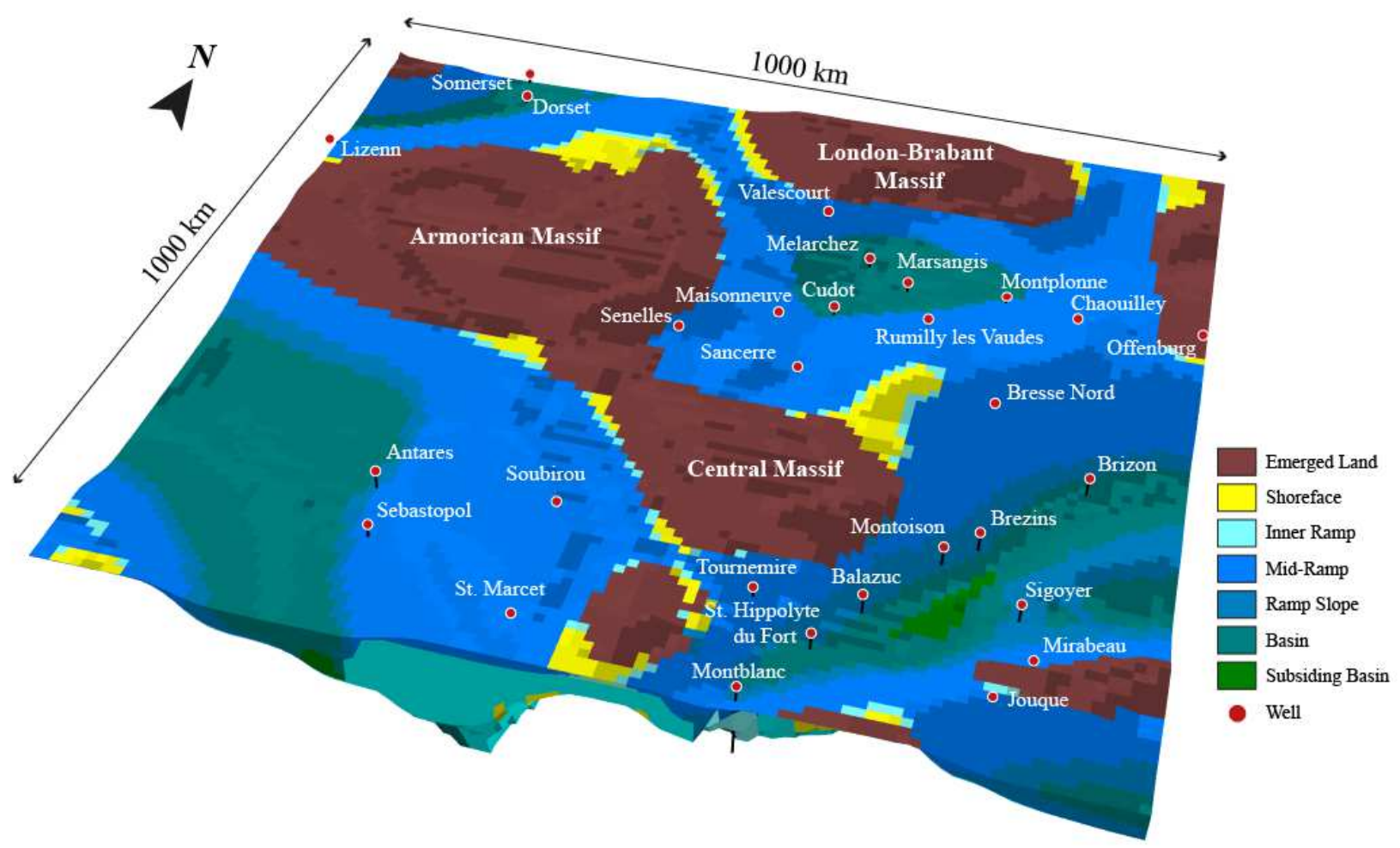

Fig. 11. 3D block of the best-fit model of the depositional environments for the end of the

Sinemurian, calibrated using facies distribution and thickness.

4.2 Global organic matter distribution and content

Despite constant boundary conditions in terms of primary productivity and dissolved oxygen

variation, the simulated TOC shows a broad range of values (from 0 to $20 \mathrm{wt}$ \%). Areas with high

TOC content (source rock) can be simulated using internal factors alone (e.g. basin morphology,

bathymetry and sedimentation rate) without involving external factors (e.g. oceanic anoxic events, 
upwelling). TOC maps show organic-rich areas that are relatively limited in space even during the

Toarcian. These areas are most often located in the depocentres and less frequently in the proximal areas of the basins.

Our results cannot be compared against data from areas that are nowadays eroded or highly deformed (e.g. current rim of the Paris Basin, eastern part of the South-East Basin, Bresse-Jura and Poitou threshold). However, despite the constant primary production and the absence of any variations of dissolved oxygen level linked to other factors such as primary productivity or bathymetry, the distribution of organic-rich sediments given by our model fits with available data. To highlight the reliability of the model, we present close-up views of some cross-sections and wells (Figs. 12, 13, 14 and 15). 


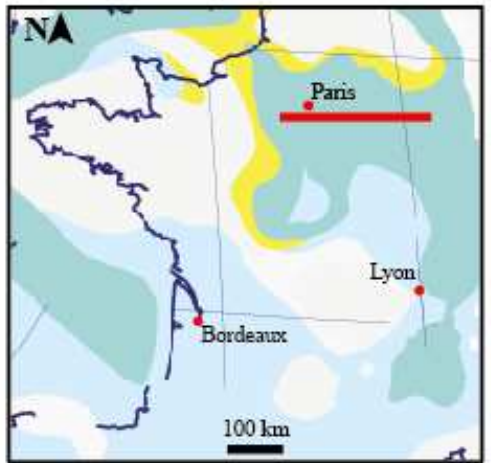

Modelled area and cross section (red line) in the Paris Basin
W Paris E

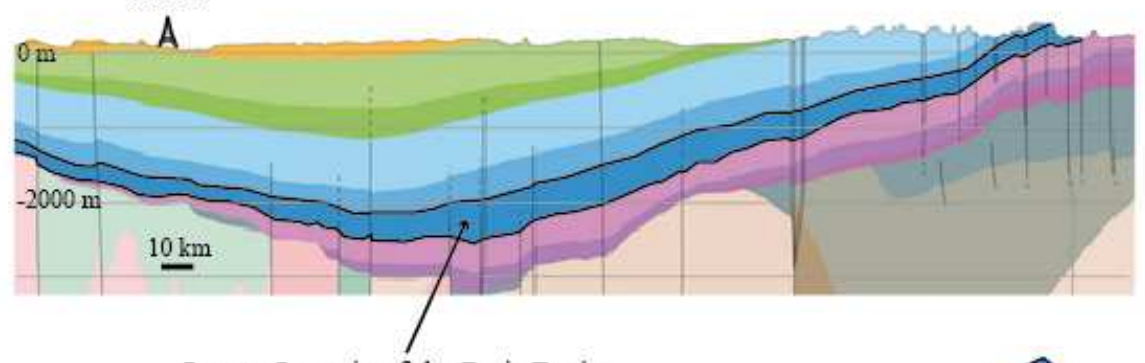

Lower Jurassic of the Paris Basin in current structural position

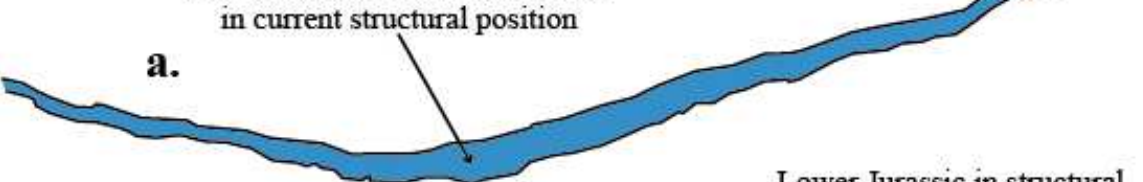

Lower Jurassic in structural position at the end of Toarcian

$\overbrace{0=2}^{\operatorname{TOC}(w t \%)}$ b.
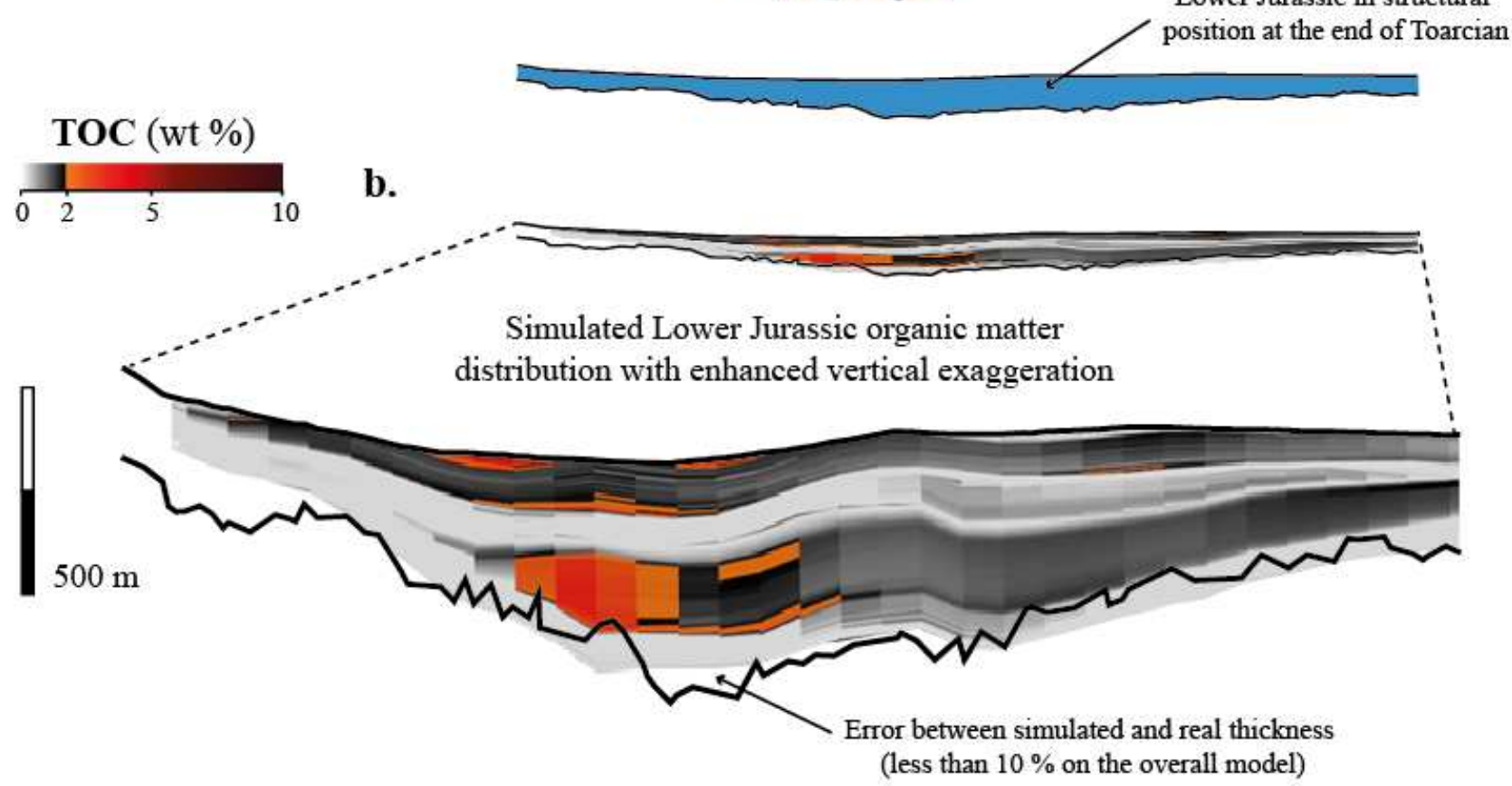

Fig. 12. a. Cross-section of the Paris Basin in current structural position and at the end of the

Toarcian (modified after Gély and Hanot, 2014). b. Simulated thickness and initial TOC distribution. 


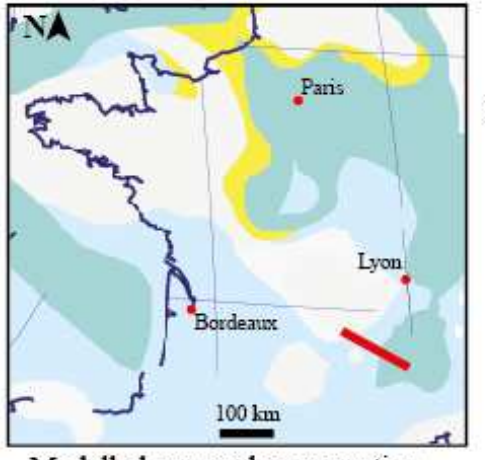

Modelled area and cross section (red line) in the Sud-Est Basin

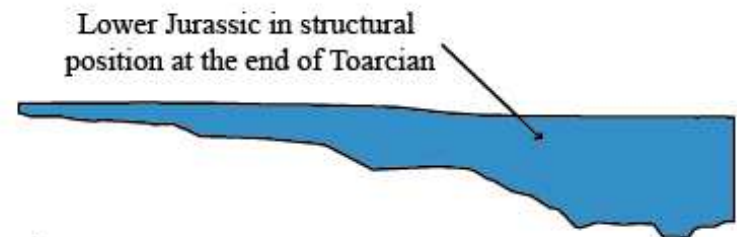

b.

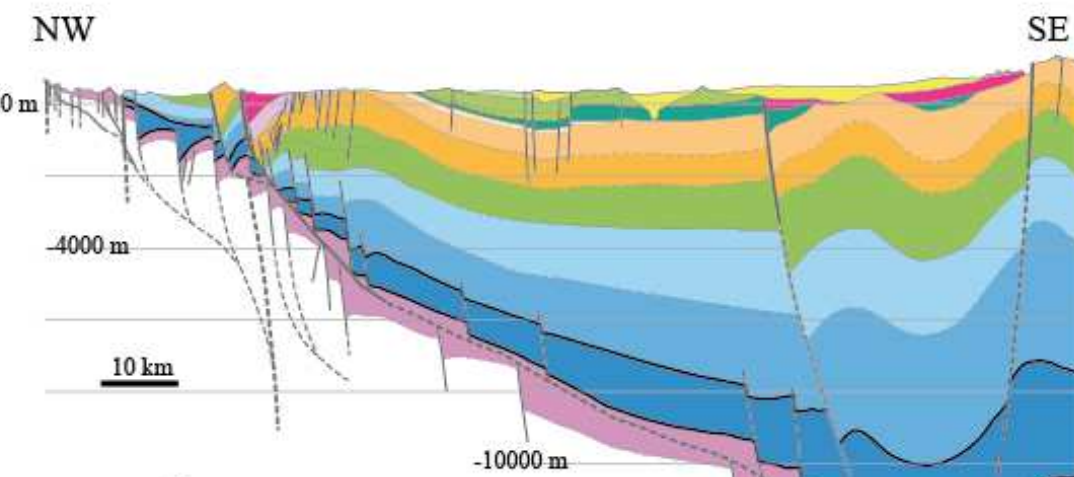

a.

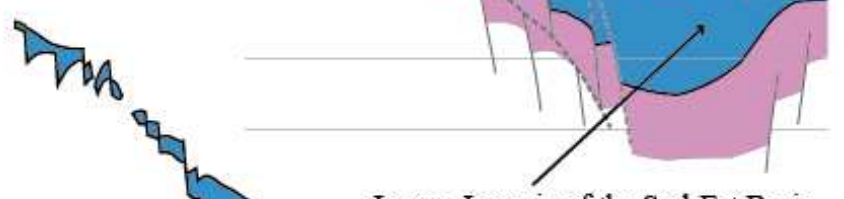

Lower Jurassic of the Sud-Est Basin in current structural position

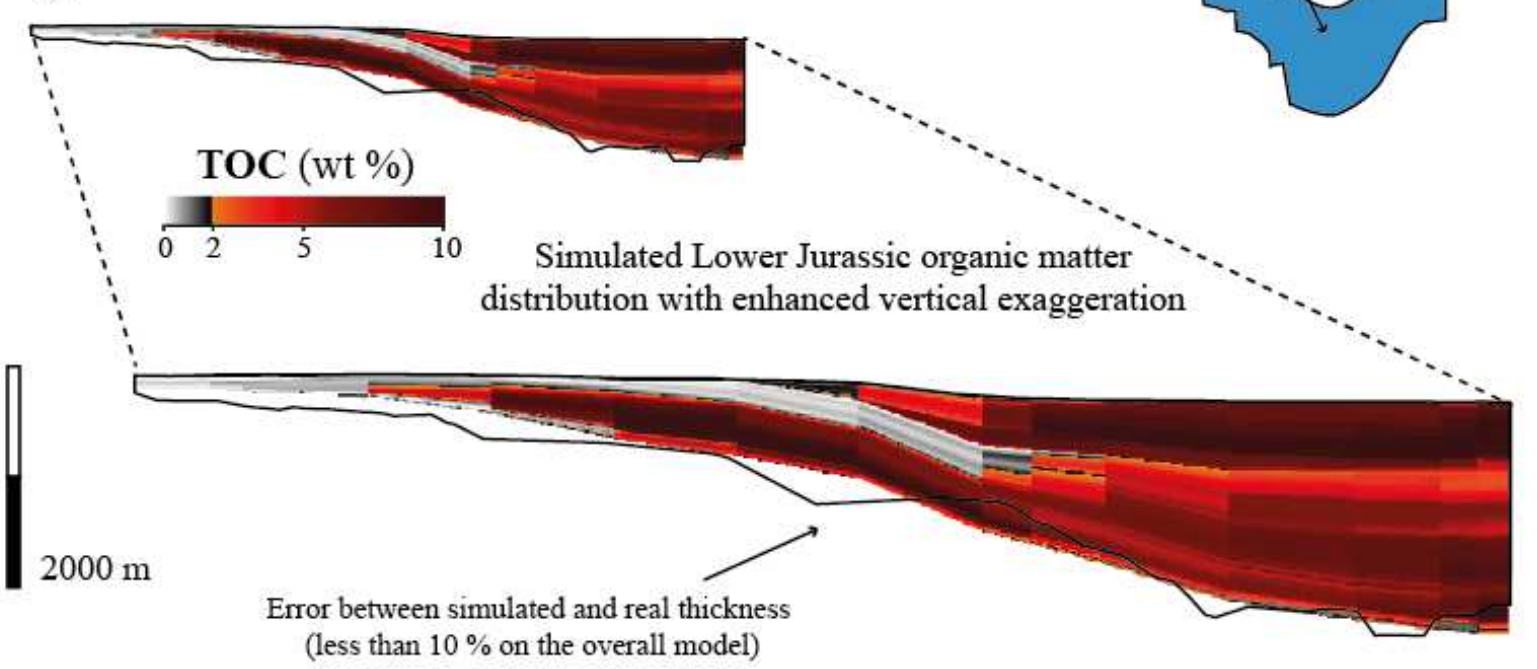

Fig. 13. a. Cross-section of the South-East Basin in current structural position and at the end of the

Toarcian (modified after Benedicto et al., 1996). b. Simulated thickness and initial TOC distribution.

Black line: current position of the Lower Jurassic, but abrupt changes corresponding mainly to post-

depositional faults are not modelled here. 


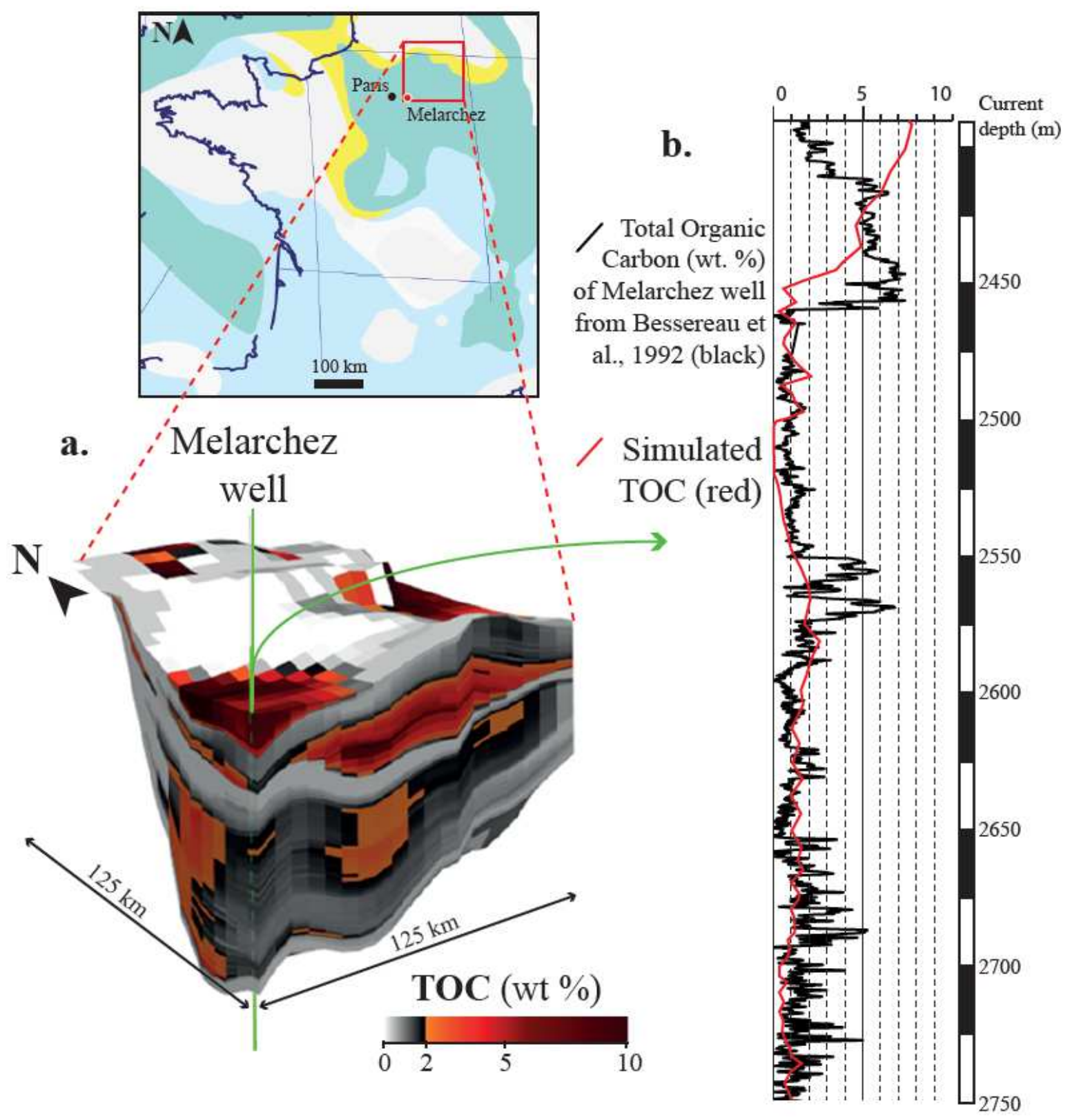

Fig. 14. a. Simulated initial TOC distribution of the north-eastern sector of the Paris Basin at the end of the Early Toarcian. b. Comparison between simulated initial TOC and measured TOC. Discrepancies are mainly due to the input of terrestrial organic matter in the lower part of the well section, which enhances the TOC value but which is not simulated in our model. 

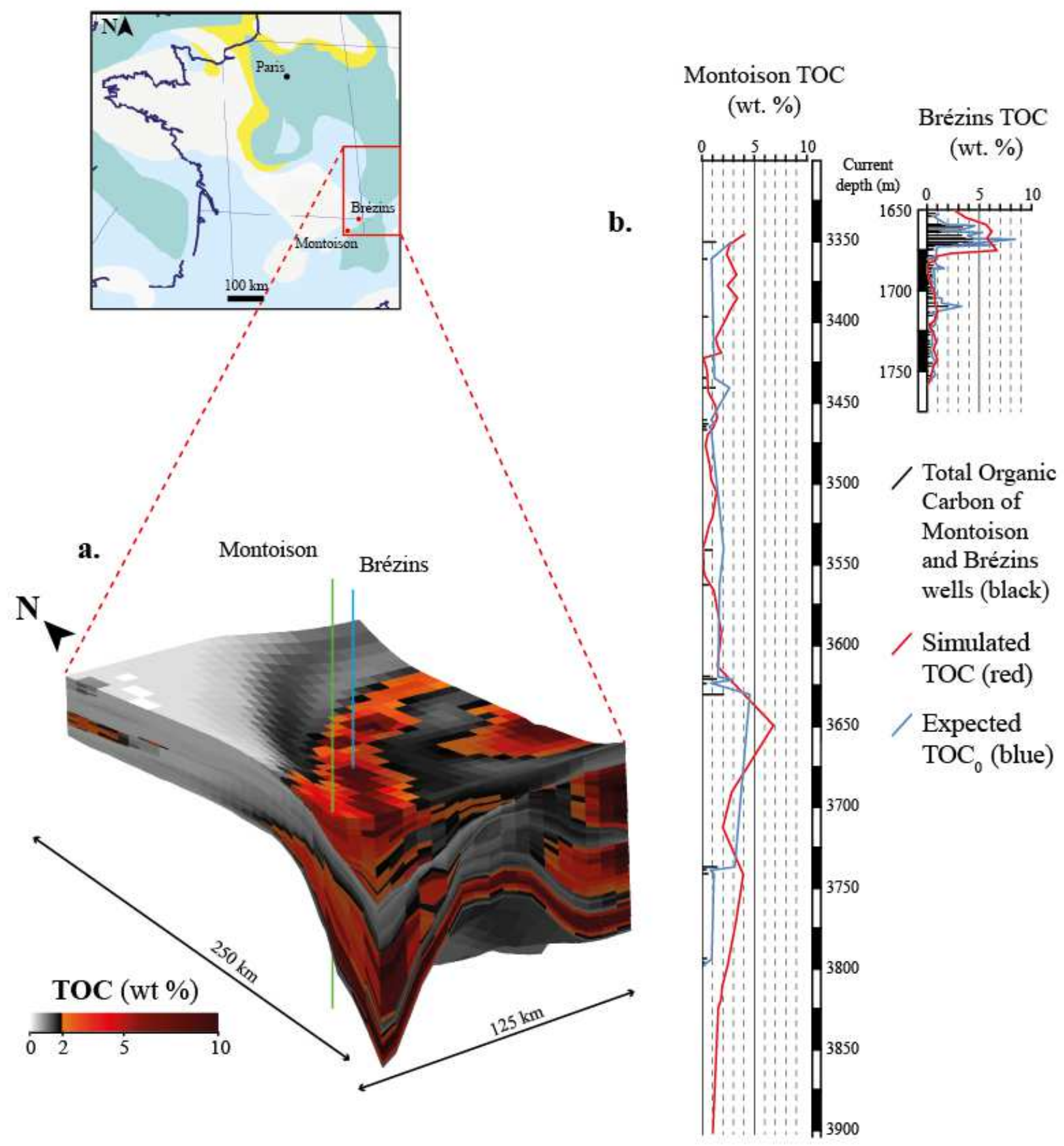

Fig. 15. a. Simulated initial TOC distribution of the South-East basin at the end of the Early

Toarcian. $b$. Comparison between simulated initial TOC, measured TOC and initial TOC calculated with Jarvie et al. (2007) computation (TOC $)$. 
Nonetheless, we can note a misfit between the simulated TOC and the well data. The first difference stems from the burial effect, which is particularly evident in the Aquitaine and South-East basins where organic-rich layers can be buried under more than $10 \mathrm{~km}$ of Mezosoic and Cenozoic deposits (Fig. 13 and 15). In these areas, our model shows thick organic-rich layers with initial TOC reaching 20 wt. $\%$ as against 5 wt. $\%$ in wells. The burial and maturation history leads to expulsion of a large proportion of the organic matter, which hinders any comparison between modelling and well data. In the rest of the model, the overall trends of organic matter content in the sediments are well reproduced (Fig. 12 and 14). The 0.1-Myr time steps yield an average TOC over intervals ranging from a few $\mathrm{cm}$ to more than $10 \mathrm{~m}$ depending on the sedimentation rate. Hence, higher frequency variations are not taken into account in our modelled TOC values, and comparisons need to be performed using the trends and average measured values of each interval (the TOC curve is derived from logging data, with a value every 0.1 to $5 \mathrm{~m}$, whereas the thickness of the model grid cells, based on time steps, varies from 0 to $10 \mathrm{~m}$ ). The duration of TOC pulses and the importance of the time scale in comparing the simulated and measured TOC remains an open question. Furthermore, to achieve an accurate fit with the TOC data, we need to consider the time-evolution of primary production and dissolved oxygen levels (e.g. Toarcian anoxic event). 


\section{Discussion}

\subsection{Organic-rich sediment depocentres}

The main organic-rich deposits are located in depocentres of the basins. This is particularly well seen in the Paris and South-East basins (Fig. 12, 13, 16 and 17-f.) in the models. The initial TOC values exceeds $4 \%$ and can reach 6 wt. \% over intervals up to tens of metres thick. These areas are mainly composed of shaly-marly to shaly facies with high sedimentation rates (around 50 to $70 \mathrm{~m} . \mathrm{Myr}^{-1}$ ), which are always located several hundreds of $\mathrm{km}$ from the coastline (from 100 to $300 \mathrm{~km}$ ). Therefore, in our modelling, the primary productivity at the sea surface directly above these deposits is quite low and never higher than $200 \mathrm{gC} \cdot \mathrm{m}^{-2} \cdot \mathrm{yr}^{-1}$, since it decreases as a function of distance from the coast (Fig. 17-d.). The depocentres also correspond to the deepest part of the basins, with minimum water depths varying from $150 \mathrm{~m}$ for the Paris Basin (Fig. 17-b.) to $400 \mathrm{~m}$ for the SouthEast Basin. Under these conditions, the dissolved oxygen level can become drastically lowered (e.g. South-East Basin) or simply depleted (e.g. Paris Basin, Fig. 17-e.). This oxygen depletion is due solely to bathymetry because the high primary productivity zones are too far away to have a noticeable effect on oxygen consumption. However, the highest TOC values are not found in the area with optimum sedimentation rate (between 40 and $60 \mathrm{~m} \cdot \mathrm{My}^{-1}$ ), but in areas with lower sedimentation rate (>40 $\mathrm{m} \mathrm{My}^{-1}$, Fig. 17-c.) In such environments, the preservation of organic matter is already 
ensured by oxygen-depleted conditions, thus the lower sedimentation rate results in less dilution of the TOC signal.

In terms of sequence stratigraphy, these conditions are developed during transgressive phases, and the maximum spatial extent of these deposits is reached during or at the end of the maximum flooding tract. These criteria are also reached during regressive phases provided there is still a significant subsidence and sediment accumulation in the deepest part of the basins. 


\section{ACCEPTED MANUSCRIPT}

UPPER SINEMURIAN

SOURCE ROCK

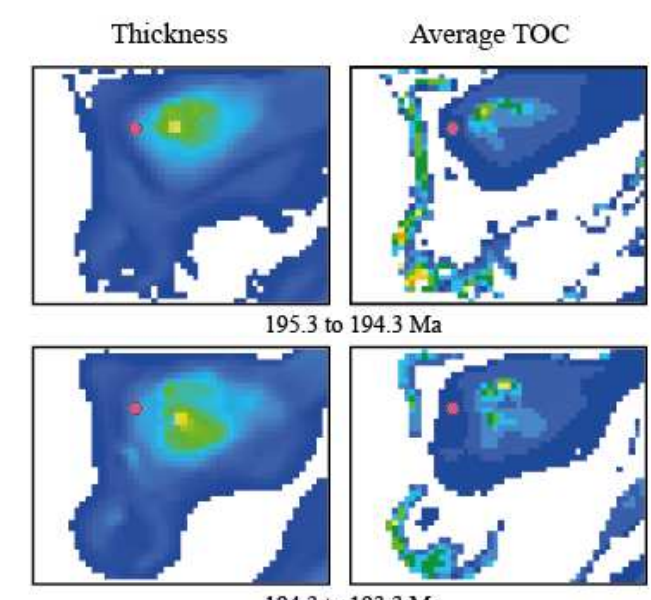

194.3 to $193.3 \mathrm{Ma}$

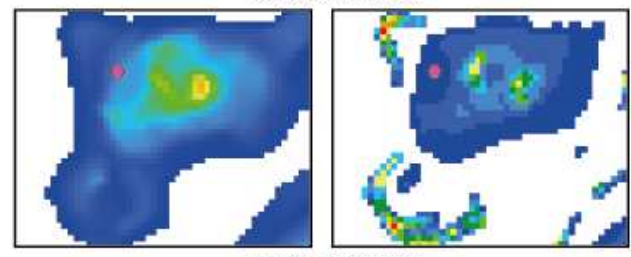

193.3 to $192.3 \mathrm{Ma}$

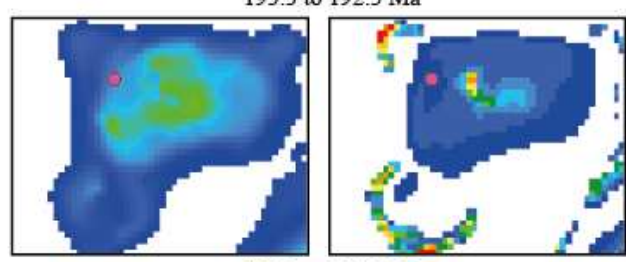

192.3 to $191.3 \mathrm{Ma}$

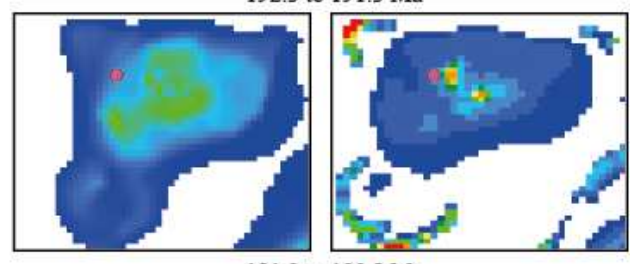

191.3 to $190.3 \mathrm{Ma}$

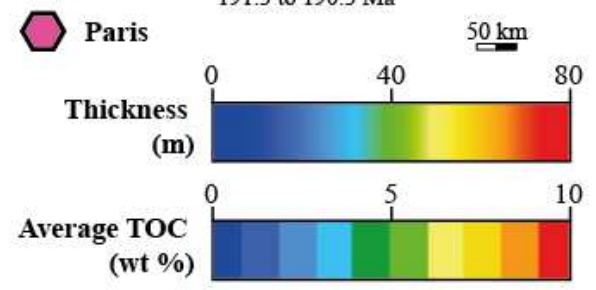

\section{LOWER-MIDDLE TOARCIAN}

SOURCE ROCK

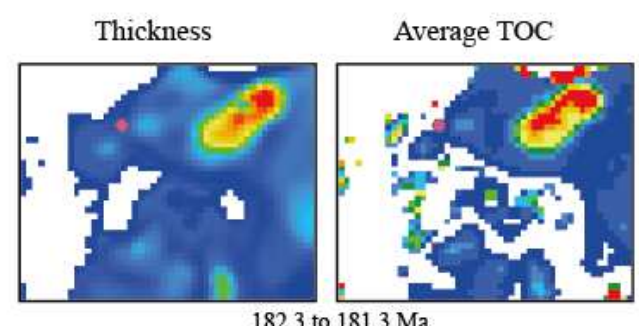

182.3 to $181.3 \mathrm{Ma}$

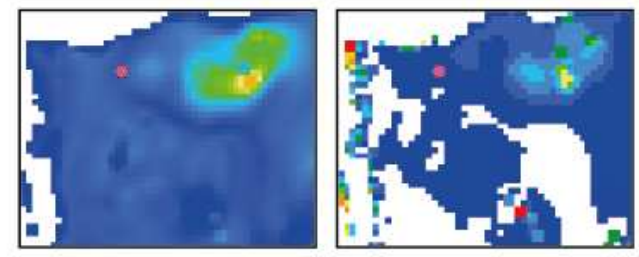

181.3 to $180.3 \mathrm{Ma}$

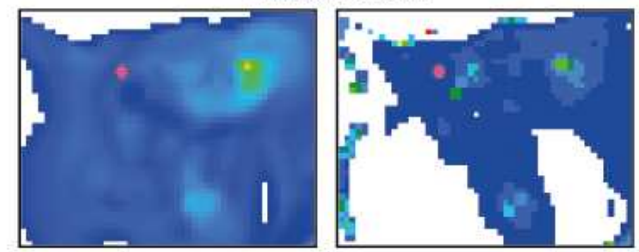

180.3 to $179.3 \mathrm{Ma}$

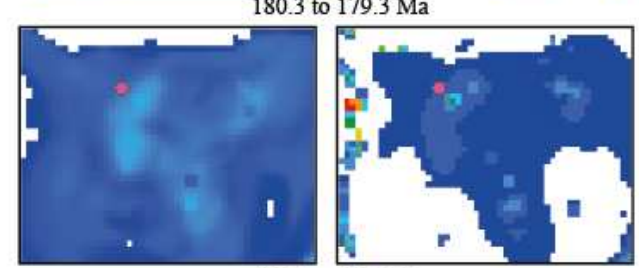

179.3 to $178.3 \mathrm{Ma}$

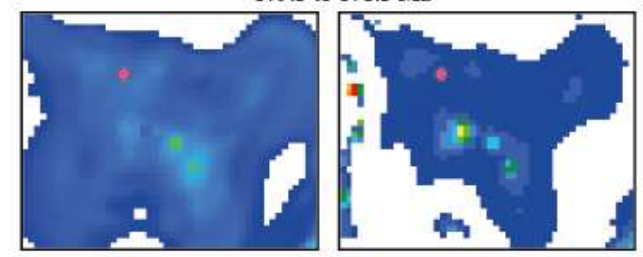

178.3 to $177.3 \mathrm{Ma}$

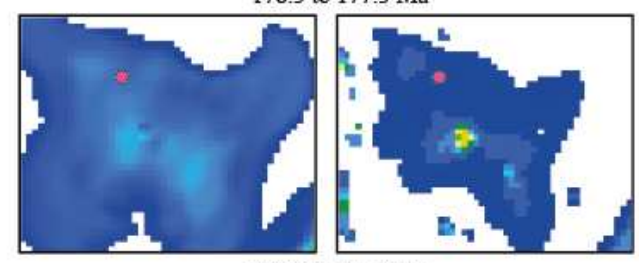

177.3 to $176.3 \mathrm{Ma}$

Fig. 16. Thickness and TOC distribution of Sinemurian and Toarcian source rocks in the Paris

Basin. The Sinemurian organic-rich deposits are located in the same area, while the Toarcian organic-rich deposits follow the migration of the depocentres. Very thin layers with high TOC content are also found in proximal areas in the western part of the basin. 


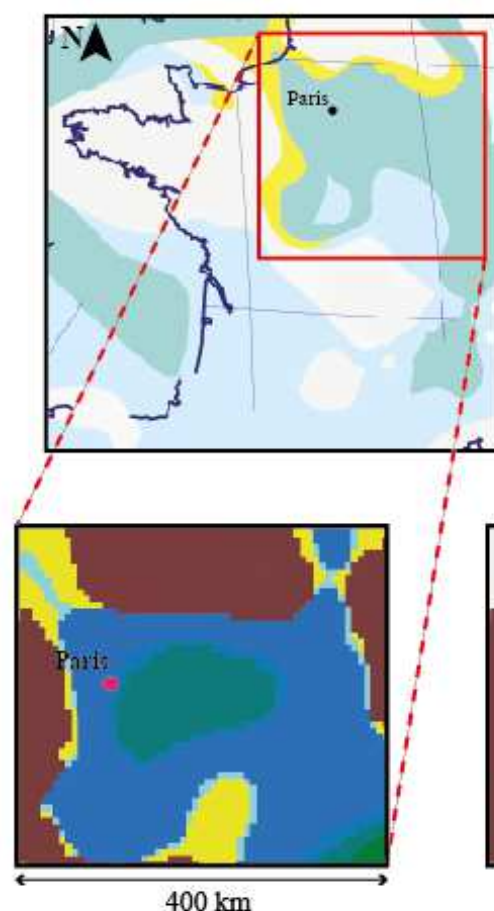

a. Facies

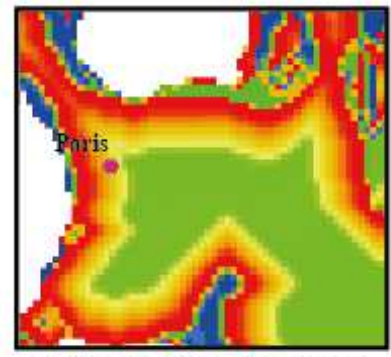

Primary Productivty

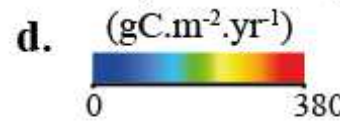

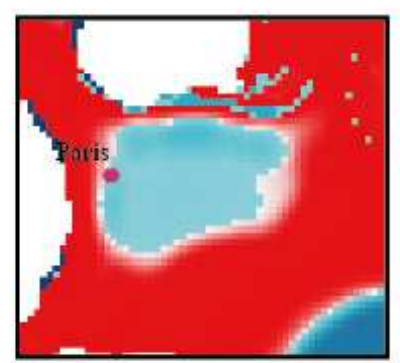

Oxygen

e.

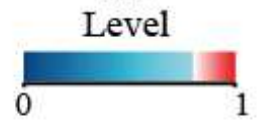

$\mathrm{TOC}_{0}$ (wt. \%)

(Espitalié et al., 1987)

g.

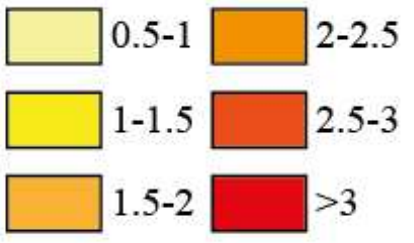

Upper Sinemurian of the Paris Basin

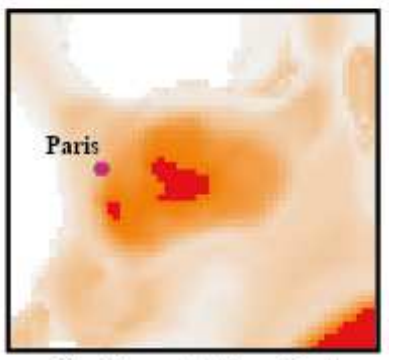

Sedimentation Rate
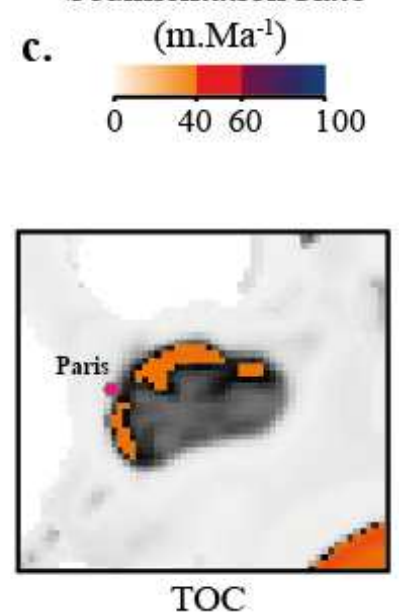

f. $\frac{(\text { wt. \%) }}{0-2}$

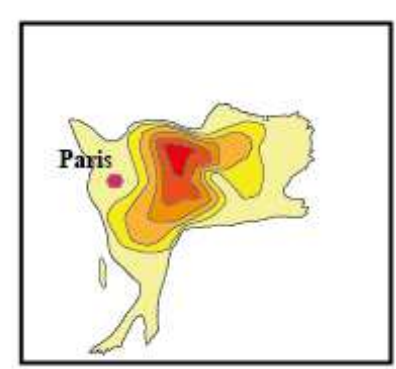

Fig. 17. Modelling results for a time slice in the Late Sinemurian. Facies TOC 0 map after Espitalié et al., 1987). 
In view of these results, it seems that the accumulation of thick organic-rich layers is more closely related to the transport of shales in the deepest part of the basin. Passey et al. (2010) has described this type of distribution as a distal parasequence on the platform ramp. When the carbonate ramp attains a greater water depth, this leads to preferential accumulation of shales and organic matter. This setting is therefore more closely related to water depth than the development of a chronostratigraphic sequence. In the model results, we observe organic-rich depocentres in both regressive and transgressive phases. However, these phases have an effect on the distribution of the organic-rich deposits: their accumulation is always associated with the onset transgression (when bathymetry is sufficient to ensure gradation of carbonate ramp into basinal facies) and then spreads during the rest of the transgression as described by Wignall (1991) and Röhl and Schmid-Röhl (2005). But, as the carbonate ramps invade the emerged land, the shaly and organic-rich facies also shift towards the proximal domain. According to two main scenarios, sedimentation is a function of the slope gradient and the size of the basin (which themselves depend on sediment accumulation and subsidence): (i) if the slope gradient is steep enough, the shales and organic matter continue to be accumulated on top of the previous depocentre and can even spread toward the proximal part (e.g. South-East basin) (Fig. 14) as described by Wignall (1991), (ii) if the slope is gentle in the deepest part, the organic matter is accumulated directly at the extremity of the carbonate ramp and a smaller proportion is transported basinwards where it is further diluted by shales (e.g. Paris Basin) (Fig. 16 and 17). This results in an organic-rich "ring" surrounding moderately rich deposits in the core of the 
basin (Fig. 17). Clearly, the relatively shallow epicontinental basin setting allows the development of organic-rich deposits, which might not be the case in other sedimentary basins. This phenomena also reflects the impact of sedimentation rate: in the case of the Paris Basin, under fairly well oxygenated conditions, sedimentation rates higher than $40 \mathrm{~m} . \mathrm{My}^{-1}$ increase the preservation of organic matter due to fast burial and isolation from oxygen. However, if the sedimentation rate exceeds $60 \mathrm{~m}$. $\mathrm{My}^{-1}$, even if the preservation is increased, dilution will reduce the TOC of the sediment (Ibach, 1982; Zonneveld et al., 2010). This optimal window allows a good preservation of organic matter in areas where dissolved oxygen levels remain high. In dysoxic to anoxic environments, the preservation is already ensured and lower sedimentation rates lead to lower dilution at higher TOC (Fig. 17).

Furthermore, a migration of organic-rich sediment can be observed across the basin. This is clearly seen in the Paris Basin (Fig. 16), where the Toarcian high-TOC deposits migrate in the same direction as the depocentre, associated with good preservation conditions. In this way, while any given organic-rich horizon can be followed throughout the basin, the deposits are diachronous as already assumed in the literature (e.g. Jenkyns et al., 2002; Mailliot et al., 2006; Hesselbo et al., 2007).

\subsection{Proximal areas}


Other organic-rich deposits can sometimes be observed in proximal areas at distances of 10 to $30 \mathrm{~km}$ from the coastline. In such settings, the initial TOC values are around 3 to $6 \mathrm{wt}$. $\%$ and the organicrich layers are never more than a few meters thick, but can be followed for several $\mathrm{km}$ parallel to the shore. These deposits formed in shallow-water environments are composed of carbonates and/or clastics, with sedimentation rates of less $20 \mathrm{~m} \cdot \mathrm{My}^{-1}$. The water depth can vary from a few to several tens of meters. Because of the proximity to the coastline, the sea-surface primary productivity in these areas is high (from 300 to $400 \mathrm{gC} \cdot \mathrm{m}^{-2} \cdot \mathrm{yr}^{-1}$ ). Even if this high primary productivity leads to high consumption of oxygen, the shallow water depths allow an efficient renewal, and these environments are fully oxygenated. These depositional environments develop during transgressive phases, when the accumulation of thin organic-rich layers is favoured by the topography of the carbonate ramp. Since the proximal deposits of the ramp are relatively flat, restricted depressions can form because of differential subsidence or clastic supply. In this case, even if the level of dissolved oxygen theoretically leads to the total degradation of organic matter, the accumulation of sediments is concentrated in local depressions, especially since organic matter is transported as silt-sized particles that are abundant in high primary productivity areas. The sedimentation rate can locally reach the optimal windows described above and thus enhance the preservation of organic matter.

The same process can be observed during regressive phases on confined sills (e.g. modelled Causses and Poitou sill). Here, the proximity of emerged land leads to high primary productivity (300 to 400 $\mathrm{gC} \cdot \mathrm{m}^{-2} \cdot \mathrm{yr}^{-1}$ ) over very large areas. TOC values higher than $5 \mathrm{wt}$ \% can be found because of the high organic matter content of sediments deposited on this threshold. Organic-rich layers can be deposited 
even if the environment is fully oxygenated and with sedimentation rates below the optimal windows. However, more open thresholds (e.g. modelled Bresse-Jura area) do not display the same feature, even in cases where primary productivity is high and sedimentation rates are more favourable for organic matter preservation. These observations imply that, under the right conditions, an extensive sea area (at least $5,000 \mathrm{~km}^{2}$ ) with moderate primary productivity can lead to high TOC rather than localized areas with higher primary productivity.

\section{Conclusion}

This study aims to analyse the processes controlling organic matter distribution and heterogeneity through a numerical quantitative approach applied to the Lower Jurassic succession of north-western Europe. The 3D modelling approach allows us to incorporate a large amount of data and test multiple coupled processes. A high primary productivity as well as factors favouring organic matter preservation could theoretically create conditions for the development of high organic carbon contents in sediments. Modelling results and associated interpretations allow us to draw several conclusions concerning the evolution of organic matter and the key factors controlling its distribution and heterogeneity:

(1) Accumulation of thick organic-rich layers in depocentres are correlated with shaly-marly to shaly facies with high sedimentation rates (around 50 to $70 \mathrm{~m} \cdot \mathrm{Myr}^{-1}$ ) as well as areas with decreased dissolved oxygen levels due to isolation and/or consumption. These settings are developed during transgressive phases, and also during regressive phases if significant subsidence and sediment accumulation continues in the deepest part of the basins. 
(2) During transgression, organic matter are accumulated in depocentres on the top of previous depocentres but can also spread toward the more proximal parts of the basin.

(3) If the slope is gentle, an organic-rich "ring" is accumulated at the break-in-slope of the carbonate ramp, and a smaller proportion is transported basinward where it is further diluted by shales.

(4) Organic-rich carbonate and/or coarse clastic layers a few meters thick can be followed over several kilometres parallel to the shore; these layers can be observed during transgressive phases or during regressive phases on confined threshold. They are related to restricted depressions linked to differential subsidence and/or clastic supply in the proximal flat part of the ramp. In this setting, the water depth (from a few to several tens of meters) and sedimentation rates (less than $20 \mathrm{~m} \cdot \mathrm{My}^{-1}$ ) hinder the preservation of organic matter but, because of the proximity of the coast line, the primary productivity at the sea surface is high.

Several different favourable conditions are highlighted for the accumulation organic-rich deposits. The main factors leading to thick organic-rich deposits are sedimentation rate (between 40 and $60 \mathrm{~m}$. $\mathrm{My}^{-1}$ for a good preservation) and basin geometry (depocentre position). The main factors leading to restricted and thinner organic-rich deposits in proximal settings or on thresholds are primary productivity and the existence of local depressions. These depositional environments for organic-rich sediments are compatible with many of the conceptual models currently proposed in the literature (e.g. Wignall, 1991; Röhl and Schmid-Röhl, 2005; Passey and Bohacs 2010).

This study highlights the need for a relative quantification of the palaeo-environmental conditions and processes that lead to the widespread accumulation of organic matter. For the time interval studied here, covering 25 Myr during the Early Jurassic without any major tectonic event and without assuming any variation in primary productivity or open ocean oxygen levels, the model predicts several source rocks and TOC ranging from 0 to $20 \mathrm{wt} \%$. 
Clearly, some of our hypotheses could be challenged and the approach used to study certain processes such as organic-matter transport merits further investigation and improvement. Variations of primary productivity have an impact in the proximal parts of basins and in threshold areas, while climatic change and other external causes may also have an influence.

\section{ACKNOWLEDGMENTS}

DionisosFlow@ is developed in the framework of the IFP Energies Nouvelles project DORS (“Dionisos Organic-Rich Sediment”). We are grateful to Brigitte Doligez, Bertrand Coureaud, JeanFrançois Deronzier, Jean-Pierre Barde and Laurent Riquier for constructive discussions. We also thank Florence Savignac and Marie Salpin for laboratory technical assistance and BeicipFranlab for support with DionisosFlow@. We wish to thank Fadi H. Nader and two anonymous reviewers for their constructive remarks. Carpenter post-edited the English style and grammar.

\section{CONFLICT OF INTEREST}

No conflict of interest declared.

\section{REFERENCES}

Alzaga-Ruiz, H., Granjeon, D., Lopez, M., Seranne, M., Roure, F., 2009. Gravitational collapse and Neogene sediment transfer across the western margin of the Gulf of Mexico: insights from numerical models. Tectonophysics, 470, 21-41. 
Bailey, T.R., Rosenthal, Y., McArthur, J.M., Van De Schootbrugge, B., Thirlwall, M.F., 2003.

Paleoceanographic changes of the Late Pliensbachian-Early Toarcian interval: a possible link to the genesis of an Oceanic Anoxic Event. Earth planet science letter, 212, 307-320.

Bassoulet, J.P., Baudin, F., 1994. Le Toarcien inférieur: un épisode de crise dans les bassins et sur les plates-formes carbonatées de l'Europe du Nord-Ouest et de la Téthys. Geobios Memoire Spécial, 17, 645-654.

Bastviken, D., Persson, L., Odham, G., Tranvik, L., 2004. Degradation of dissolved organic matter in oxic and anoxic lake water. Limnology Oceanography, 49, 109-116.

Baudin, F., 1989. Caractérisation géochimique et sédimentologique de la matière organique du Toarcien téthysien (Méditerrannée, Moyen-Orient), significations paléogéographiques. Thèse Université Pierre et Marie Curie, Paris, France, 246 p.

Baudin, F., Herbin, J.P., Vandenbroucke, M., 1990. Mapping and geochemical characterization of the Toarcian organic matter in the Mediterranean Tethys and Middle East. Organic Geochemistry, 16, 677-687.

Benedicto, A., Labaume, P., Séguret, M., Seranne M., 1996. Low-angle crustal ramp and basin geometry in the Gulf of Lion passive margin: Oligocene-Aquitanian Vistrenque graben, SE France. Tectonics, 15, 1192-1212.

Berger, W.H., Smetacek, V.S., Wefer, G., 1989. Productivity of the Ocean: Present and Past. In: Dahlem Workshop Report (Ed. by Berger W.H., Smetacek V.S., Wefer G.), Berlin. Life Sciences Research Report, 44, 1-34.

Bernoulli, D., Jenkyns, H.C., 1974. Alpine, Mediterranean and central Atlantic Mesozoic facies in relation to the early evolution of the Tethys. In: Modern and Ancient Geosynclinal Sedimentation (Ed. by Dott, R.H., Shaver R.H.), Spec. Publ. Soc. econ. Paleont. Miner, 19, $129-160$. 
Bessereau, G., Huc, A.Y., Carpentier, B., 1992. Distribution of organic matter in the Liassic series of the Paris basin: an exemple of organic heterogeneity in a source rock interval. In: Generation, accumulation and production of Europe's hydrocarbons II (Ed. by Spencer A.M.), Springer, Berlin Heidelberg New York, 69-87.

Bessereau, G., Guillocheau, F., Huc, A.Y., 1995. Source rock occurrence in a sequence stratigraphic framework: the example of the Lias of the Paris Basin. In: Paleogeography, Paleoclimate, ands Source Rocks (Ed. by Huc A.Y.), Am. Assoc. Petrol. Geol. Mem., 40, 273-301.

Betts, J.N., Holland, H.D., 1991. The oxygen content of ocean bottom waters, the burial efficiency of organic carbon, and the regulation of atmospheric oxygen. Global Planet. Change, 97, 5-18.

Boulila, S., Galbrun, B., Huret, E., Hinnov, L.A., Rouget, I., Gardin, S., Bartolini, A., 2014. Astronomical calibration of the Toarcian Stage: Implications for sequence stratigraphy and duration of the early Toarcian OAE. Earth and Planetary Science Letters, 386, 98-111.

Bruneau, B., Chauveau, B., Duarte, L.V., Desaubliaux, G., Moretti, I., Baudin, F., 2016. 3D Numerical Modelling of Marine Organic Matter Distribution: example of the Early Jurassic sequences of the Lusitanian Basin (Portugal). Basin Research, in press, 1-23, doi: 10.1111/bre.12210.

Burchette, T.P.,Wright, V.P., 1992. Carbonate ramp depositional systems. Sedimentary Geology, 79, $3-57$.

Carpentier, B., Huc, A.Y., Bessereau, G., 1991. Wireline logging and source rocks - Estimation of organic carbon content by the Carbolog method. The log Analyst, 32, 279-297.

Comas-Rengifo, M.J., Duarte, L.V., Goy, A., Paredes, R., Silva, R.L., 2013. El Sinemuriense Superior (cronozonas Oxynotum y Raricostatum) en la región de S. Pedro de Moel (Cuenca Lusitánica, Portugal). Fácies carbonatadas ricas em matéria orgânica do Jurássico da Bacia Lusitânica. Novos contributos paleontológicos, sedimentológicos e geoquímicos. Comunicações Geológicas, 100, 15-19. 
Delmas, J., Houel, P., Vially, R., 2002. Rapport regional d'évaluation pétrolière - Paris Basin Petroleum Potential. Institut Français du Pétrole Regional Report, 179 p.

Disnar, J. R., Le Strat, P., Farjanel, G., Fikri, A., 1996. Sedimentation de la matière organique dans le nord-est du Bassin de Paris : conséquences sur le dépôt des argilites carbonées du Toarcien inférieur. Chemical Geology, 131, 15-35.

Dommergues, J-L., Meister, C., Neige, P., Rocha, R.B., 2004. Endemic Sinemurian (Early Jurassic) ammonites from the Lusitanian Basin (Portugal). Revue de Paléobiologie, 23(2), 529-549.

Dromart, G., Allemand, P., Garcia, J.P., Robin, C., 1996. Variation cyclique de la production carbonatee au Jurassique le long d'un transect Bourgogne-Ardèche, Est-France. Bulletin de la Société Géologique de France, 167, 423-433.

Duarte, L.V., Comas-Rengifo, M.J., Silva, R.L., Paredes, R., Goy, A., 2014. Carbon isotope stratigraphy and ammonite biochronostratigraphy across the Sinemurian-Pliensbachian boundary in the western Iberian margin. Bulletin of Geosciences, 89, 719-736.

Elmi, S., 2005. Toarcian Working Group 2005 Report and prospects. In: The Peniche section (Portugal). Candidate to the Toarcien Global Stratotype Section and Point (GSSP). (Ed. by Elmi, S., Duarte, L.V., Mouterde, R., Rocha, R.B., Soares A.F.), Caparica, 2-10.

Enay, R., Mangold, C., 1980. Synthèse paléogéographique du Jurassique Français par Le Groupe français d'Etude du Jurassique. (Coord. by Cariou, E., Contini, D., Debrand-Passard, S., Donze, P., Gabilly, J., Lefavrais-Raymond, A., Mouterde, R., Thierry, J.), Docum. Lab. Géol. Lyon, H.S. 5, 210 p., 1 fig., 3 tabl., 42 cartes.

Espitalié, J., Marquis, F., Sage, F., Barsony, I., 1987. Géochimie organique du Bassin de Paris. Revue de l'Institut Français du Pétrole, 42, 271-302.

Falkowski, P.G., Raven, J.A., 2007. Aquatic Photosynthesis, 2nd edn. Malden: Blackwell Science, 488 p.

Garrett, C., 1991. Marginal mixing theories. Atmosphere Ocean, 29(2), 313-339. 
Gély, J.P., Hanot, F., 2014. Coupe géologique du Bassin de Paris. In : Le Bassin parisien, un nouveau regard sur la Géologie (Ed. by Association des Géologues du bassin de Paris), 1 cross section.

Granjeon, D., 1996. Modelisation stratigraphique deterministe - conception et applications d'un modele diffusif 3D multilithologique. Memoires Geosciences Rennes, PhD Dissertation, Geosciences Rennes, Rennes, France.

Granjeon, D., 2009. 3D stratigraphic modeling of sedimentary basins. AAPG Search and Discovery Article \#90090@2009 Am. Assoc. Petrol. Geol. Annual Convention, Denver, Colorado.

Granjeon, D., Joseph, P., 1999. Concepts and applications of a 3-D multiple lithology, diffusive model in stratigraphic modeling. In: Numerical Experiments in Stratigraphy: Recent Advances in Stratigraphic and Sedimentologic Computer Simulations (Ed. by Harbaugh J.W., Watney W.L., Rankey E.C., Slingerland R., Goldstein R.H.), Geological Society Special Publication, 62, 197-210.

Granjeon, D., Wolf, S., 2007. 3D stratigraphic modeling in complex tectonics area. AAPG Search and Discover Article \#90063@2007 Am. Assoc. Petrol. Geol. Annual Convention, Long Beach, California.

Granjeon, D., Chauveau, B., 2014. Sedimentary basin development method using stratigraphic simulation coupled with an organic matter production and degradation model. Brevet US20140163883 A1. 12-6-2014.

Guillocheau, F., Robin, C., Allemand, P., Bourquin, S., Brault, N., Dromart, G., Friedenberg, G., Garcia, J.-P., Gaulier, J.-M., Gaumet, F., Grosdoy, B., Hanot, F., Le Strat, P., Mettraux, M., Nalpas, T., Prijac, C., Rigollet, C., Serrano, O., Vairon, J., Granjean, G., 2000. Mesocenozoic geodynamic evolution of the Paris Basin: 3D stratigraphic constraints. Geodin. Acta, 13, 189246. 
Hallam, A., Bradshaw, M.J., 1979. Bituminous shales and oolithic ironstones as indicators of transgressions and regressions. Journal of Geological Society of London, 136, 57-164.

Hanzo, M., Espitalie, J., 1993. Relation entre matière organique et sédimentation dans le Lias de Lorraine (France). Comptes Rendus de l'Académie des sciences, 2(316), 945-950.

Haq, B.U., Hardenbol. J., Vail, P.R., 1987. Chronology of Fluctuating Sea Levels Since the Triassic. Science, 235, 1156-1167.

Hardenbol, J., Thierry, J., Farley, M.B., Jacquin, T., De Graciansky, P-C., Vail, P.R., 1998. Mesozoic and Cenozoic Sequence Chronostratigraphic Framework of European Basins. In: Mesozoic and Cenozoic Sequence Stratigraphy of European Basins (Ed. by De Graciansky, P.C., Hardenbol, J., Jacquin, T. and Vail, P. R.), SEPM Special Publication 60. Chart 1 and 6. Hesselbo, S.P., Jenkyns, H.C., Duarte, L.V., Oliviera, L, 2007. Sequence stratigraphy at times of extraordinary sediment supply in the Jurassic - Formation of a pseudo-sequence boundary during the Early Toarcian Oceanic Anoxic Event? Sea level changes: records, processes and modelling Meeting, Aix-en-Provence, France.

Hollander, D.J., Bessereau, G., Belin, S., Huc, A.Y., Houzay, J.P., 1991. Organic matter in the early Toarcian shales, Paris Basin, France: a response to environmental changes. Revue de l'Institut Français du Pétrole, 46, 543-562.

Honjo, S., Manganini, S.J., Krishfield, R.A., Francois, R., 2008. Particulate organic carbon fluxes to the ocean interior and factors controlling the biological pump: a synthesis of global sediment trap programs since 1983. Progress in Oceanography, 76, 217-285.

Ibach, L.E.J, 1982. Relationship Between Sedimentation Rate and Total Organic Carbon Content in Ancient Marine Sediments. AAPG Bull., 66, 170-188.

Jarvie, D.M., Hill, J.H., Ruble, T., Pollastro, R.M., 2007. Unconventional shale-gas systems: The Mississippian Barnett Shale of north-central Texas as one model for thermogenic shale-gas assessment. AAPG Bulletin, 91, 475-499. 
Jenkyns, H.C., 1988. The Early Toarcian (Jurassic) anoxic event: stratigraphic, sedimentary and geochemical evidence. Am. J. Sci., 288, 101-151.

Jenkyns, H.C., 2010. The geochemistry of Oceanic Anoxic Events. Geochemistry, Geophysics, Geosystems, 11(3), 1-30.

Jenkyns, H.C., Jones, C.E., Gröcke, D.R., Hesselbo, S.P., Parkinson, D.N., 2002. Chemostratigraphy of the Jurassic System: applications, limitations and implications for palaeoceanography. Geological Society of London, 159, 351-378.

Kemp, D.B., Coe, A.L., Cohen, A.S., Schwark, L., 2005. Astronomical pacing of methane release in the Early Jurassic period. Nature, 437, 396-399.

Kullberg, J.C., Oloriz, F., Marques, B., Caetano, P.S., Rocha, R.B., 2001. Flat-pebble conglomerates: a local marker for Early Jurassic seismicity related to syn-rift tectonics in the Sesimbra area (Lusitanian Basin, Portugal). Sediment. Geol., 139, 49-70.

Mailliot, S., 2006. Production carbonatée pélagique par les nannofossiles calcaires au cours de l'événement anoxique du Toarcien inférieur. Thèse Université Claude Bernard, Lyon, 345 p.

Mann, U., Zweigel, J., 2008. Modeling source-rock distribution and quality variations: the organic facies modelling approach. Spec. Publ. Int. Assoc. Sedimentol., 40, 139-274.

Martin, J.H., Knauer, G.A., Karl, D.M., Broenkow, W.W., 1987. VERTEX: carbon cycling in the northeast Pacific. Deep-Sea Research, 34, 267-285.

Mattioli, E., Pittet, B., Bucefalo Palliani, R., Röhl, H.J., Morettini, E., 2004a. Phytoplankton evidence for the timing and correlation of palaeoceanographical changes during the early Toarcian oceanic anoxic event (Early Jurassic). Geological Society of London, 161, 685-69.

Mattioli, E., Pittet, B., Young, J.R., Bown, P.R., 2004b. Biometric analysis of PlienbaschianToarcian (Lower Jurassic) coccoliths of the family Biscutaceae: intra- and interspecific variability versus palaeoenvironmental influence. Marine Micropaleontology, 52, 5-27. 
McArthur, J.M., Donovan, D.T., Thirlwall M.F., Fouke, B.W., Mattey, D., 2000. Strontium isotope profile of the early Toarcian (Jurassic) oceanic anoxic event, the duration of ammonite biozones, and belemnite palaeotemperatures. Earth planetary science letter, 179, 269-285.

Nordlund, U., 1996. Formalizing geological knowledge - With an example of modeling stratigraphy using fuzzy logic. J. Sediment. Res., 66, 689-698.

Ogg, J.G., Hinnov, L.A., 2012. Jurassic. In: The Geologic Time Scale, 2012 (Ed. by Gradstein, F.M., Ogg, J.G., Schmitz, M.D., Ogg, G.), Elsevier, Oxford, Amsterdam, Waltham, 731-791.

Passey, Q.R., Bohacs, K.M., Esch, W.L., Klimentidis, R., Sinha, S., 2010. From Oil-Prone Source Rock to Gas-Producing Shale Reservoir - Geologic and Petrophysical Characterization of Unconventional Shale Gas Reservoirs. Society of Petroleum Engineers. International Oil and Gas Conference and Exhibition in China, 8-10 June, Beijing, China.

Pilson, M.E.Q., 2012. An introduction to the chemistry of the sea. Cambridge University Press, 287294.

Pompeckj, J.F., 1901. Der Jura zwischen Regensburg und Regenstauf: Geognostische Jahreshefte, 14, 139-220.

Rabineau, M., Berne, S., Aslanian, D., Olivet, J.-L., Joseph, P., Guillocheau, F., Bourillet, J.-F., Ledrezen, E., Granjeon, D., 2005. Sedimentary sequences in the Gulf of Lion: a record of 100,000 years climatic cycles. Mar. Petrol. Geol., 22, 775-804.

Röhl, H.J., Schmid-Röhl, A., 2005. Lower Toarcian (upper liassic) black shales of the central European epicontinental basin: a sequence stratigraphic case study from the SW German Posidonia shale. SPM Special Publication, 82, 165-189.

Romero-Sarmiento, M., Ducros, M., Carpentiera, B., Lorant, F., Cacas, M-C., Pegaz-Fiornet, S., Wolf, S., Rohais, S., Moretti, I, 2013. Quantitative evaluation of TOC, organic porosity and gas retention distribution in a gas shale play using petroleum system modeling: Application to the Mississippian Barnett Shale. Mar. Petrol. Geol., 45, 315-330. 
Sathyendranath, S., Platt, T., 2013. Primary Production Distribution. Reference Module in Earth Systems and Environmental Sciences, 2013, Current as of 24 November 2014.

Schieber, J., Southard, J., Thaisen, K., 2007. Accretion of Mudstone Beds from Migrating Floccule Ripples. Science, 318, 1760-1763.

Schlanger, S.O., Jenkyns, H.C., 1976. Cretaceous oceanic anoxic event: causes and consequences. Geologie en Mijnbouw, 55, 179-184.

Steckler, M.S., Swift, D.J.P., Syvitski, J.P., Goff, J.A., Niedoroda, A.W., 1996. Modeling sedimentology and stratigraphy of continental margins. Oceanography, 9, 183-188.

Syvitski, J.P.M., Hutton, E.W.H., 2001. 2D SEDFLUX 1.0C: An advanced process-response numerical model for the fill of marine sedimentary basins. Computer and Geoscience, 27, $731-753$.

Thierry, J., 2010. Paleogeographic map of Late Sinemurian. In: Atlas peri-Tethys palaeogeographical maps (Ed. by Dercourt, J., Gaetani, M., Vrielynck, B, Barrier, E., BijuDuval, B., Brunet, M.F., Cadet, J.P., Crasquin, S., Sandulescu, M.) Peri-Thehys Programme, 1 map.

Thierry, J., Barrier, E., 2010. Paleogeographic map of Middle Toarcian. In: Atlas peri-Tethys palaeogeographical maps (Ed. by Dercourt, J., Gaetani, M., Vrielynck, B, Barrier, E., BijuDuval, B., Brunet, M.F., Cadet, J.P., Crasquin, S., Sandulescu, M.) Peri-Thehys Programme, 1 map.

Tyson, R.V., 1995. Sedimentary Organic Matter: Organic facies and palynofacies. Chapman and Hall, London, 615 p.

Tyson, R.V., 1996. Sequence-stratigraphical interpretation of organic facies variations in marine siliclastic systems: General principles and application to the onshore Kimmeridge Clay Formation, UK. S. P. In: Sequence Stratigraphy in British Geology (Ed. by Hesselbo S.P., Parkinson D.N.), Geol. Soc. Spec. Publ., 103, 75-96. 
Van Breugel, Y., Baas, M., Schouten, S., Mattioli, E., Sinninghe Damsté, J.S., 2006. Isorenieratane record in black shales from the Paris Basin, France: Constraints on recycling of respired CO2 as a mechanism for negative carbon isotope shifts during the Toarcian oceanic anoxic event. Paleoceanography, 21, 1-8.

Wannesson, J., Bessereau, G., 1999. Bassin du Sud-Est. Rapport régional d'évaluation pétrolière. Institut Français du Pétrole, 161 p.

Wignall, P.B., 1991. Model for transgressive black shales? Geology, 19, 167-1704.

Wilson, R.C.L., Hiscott, R.N., Willis, M.G., Gradstein, F.M., 1989. The Lusitanian Basin of westcentral Portugal: mesozoic and Tertiary tectonic, stratigraphic and subsidence history. In: Extensional Tectonics and Stratigraphy of the North Atlantic Margin (Ed. by Tankard, A.J., Balkwill, H.R.), AAPG Memoir, 46, 341-361.

Zonneveld, K.A.F., Versteegh, G.J.M., Kasten, S., Eglinton, T.I., Emeis, K.-C., Huguet, C., Koch, B.P., De Lange, G.J., De Leeuw, J.W., Middelburg, J.J., others, 2010. Selective preservation of organic matter in marine environments; processes and impact on the sedimentary record. Biogeosciences, 7, 483-511. 